\title{
CASE HISTORY STUDIES OF ENERGY CONSERVATION IMPROVEMENTS IN THE MEAT INDUSTRY
}

June 1982

Work Performed Under Contract No. AC06-76RL01830

Pacific Northwest Laboratory

Richland, Washington

\section{U. S. DEPARTMENT OF ENERGY}

Division of Industrial Energy Conservation 


\title{
DISCLAIMER
}

\begin{abstract}
"This report was prepared as an account of work sponsored by an agency of the United States Government. Neither the United States Government nor any agency thereof, nor any of their employees, makes any warnanty, express or implied, or assumes any legal liability or responsibility for the accuracy, completeness, or usefulness of any information, apparatus, product, or process disclosed, or represents that its use would not infringe privately owned rights. Reference herein to any specific commercial product, process, or service by trade name, trademark, manufacturer, or otherwise, does not necessarily constitute or imply its endorsement, recommendation, or favoring by the United States Government or any agency thereof. The views and opinions of authors expressed herein do not necessarily state or reflect those of the United S tates Government or any agency thereof."
\end{abstract}

This report has been reproduced directly from the best available copy.

Available from the National Technical Information Service, U. S. Department of Commerce, Springfield, Virginia 22161.

Price: Printed Copy A05

Microfiche A01

Codes are used for pricing all publications. The code is determined by the number of pages in the publication. Information pertaining to the pricing codes can be found in the current issues of the following publications, which are generally available in most libraries: Energy Research Abstracts, (ERA); Government Reports Announcements and Index (GRA and I); Scientific and Technical Abstract Reports $(S T A R)$; and publication, NTIS-PR-360 available from (NTIS) at the above address. 
CASE HISTORY STUDIES OF ENERGY CONSERVATION IMPROVEMENTS IN

THE MEAT INDUSTRY

June 1982

Prepared for the U.S. Department of Energy under Contract DE-ACO6-76RLO 1830

Pacific Northwest Laboratory Richland, Washington 99352 
,

• - 


\section{ACKNOWLEDGMENTS}

The following firms provided information or services, or both, in support of this document:

- Seattle Rendering Works

- The American Meat Packing Corporation

- Armour Food Company

- Swift and Company

- North Georgia Rendering Company

- Sam Kane Beef Processors, Incorporated

- Land O'Lakes, Incorporated

- Oscar Mayer and Company 
$\underline{\text { CONTENTS }}$

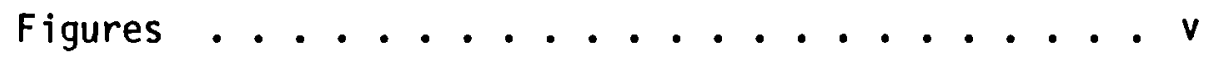

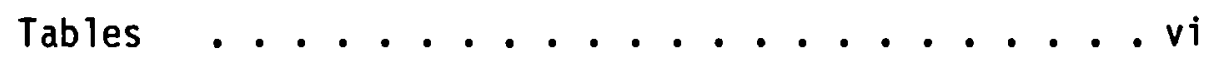

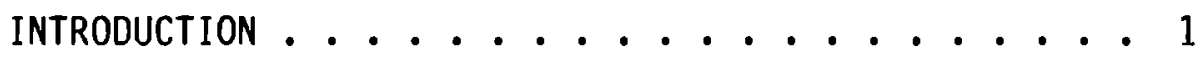

1. Continuous Rendering .......... 4

2. High-Pressure Return on Boiler .......13

3. Heat Recovery from Condensate Return and

Flash Steam .............. 21

4. Cont inuous Whole Blood Processing ...... 29

5. Preheating of Process Water with Recovered

Refrigeration Waste Heat ....... . 37

6. Continuous Rendering of Poultry Scraps .... 43

7. Electrical Stimulation of Beef .......50

8. Preheating and Storing Process Water with Recovered Refrigeration waste Heat ..... 56

9. Microcomputer Control System ........ 63

10. Housekeeping Improvements ......... 70 
FIGURES

1.1 Process Flowsheet . . . . . . . . 8

1.2 Side View and Cross Section of Continuous Cooker............... 9

2.1 System Before High-Pressure Return on Boiler . . 16

2.2 System After High-Pressure Return on Boiler . . 18

3.1 Heating of Boiler Feedwater Before Modification ............ . . 24

3.2 Steam Condensate Flow and Heating of Boiler Feedwater After Modification ....... 24

3.3 Heating of Plant Hot Water Before Modification ........... 25

3.4 Flash Steam Flow and Heating of Plant Hot Water after Modification....... 25

4.1 Conventional Blood Drying ........ 33

4.2 Continuous Blood Drying ........ 33

4.3 Decanter Centrifuge . . . . . . . 34

5.1 Process Components Before Modification to Refrigeration Waste-Heat Recovery Systems . . 40

5.2 Preheating Process Water with Recovered Refrigeration Waste Heat ........ 41

6.1 Batch Rendering System . . . . . . . 46

6.2 Continuous Rendering System . . . . . . 47

8.1 Plant Process Components Prior to Modification for Waste Heat Recovery ...... 58

8.2 Preheating and Storage of Process Water with Recovered Waste Heat ........ 61

9.1 Component Interconnections of a Typical Microcomputer Energy Management System (after McQuay-Perflex, Inc.) . . . . . 67 


\section{TABLES}

10.1 Energy Usage . . . . . . . . . . . 77

10.2 Housekeeping Cost Savings . . . . . . 78 


\section{INTRODUCTION}

This report presents case histories for ten energy-efficient technologies implemented by the meat industry. Basic information is provided about how the technologies work, the new equipment needed, and the plant modifications required to adopt the technology. Energy cost savings are reported, and the secondary benefits of the changeover, such as increased production capacity or improved product quality, are also described.

The development of several of these technologies was funded by the Department of Energy, including:

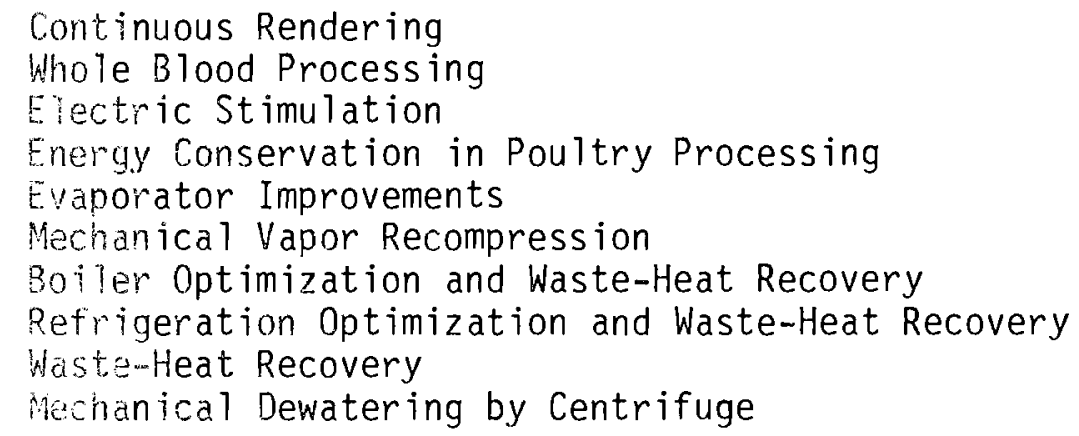

The first four technologies relate primarily to the meat industry, while the last six can be applied to other industries, as wel1.

Information for the case histories was gathered through extensive literature searches, a review of the Department of Energy reports, and persona! visits to the plant sites by the project team. The data collected for this report are presented in the following order for each case:

- Name of plant employee with address and telephone number

- Description of product or products

Energy consumption and costs at the plant before and after implementation of energy-conserving technology

- Description of the investment decision process

- Changes in production or product quality as a result of the new equipment.

The following table provides an overview of the amount of energy conserved by the various conservation measures. 
Summary of Energy Savings and Capital Cost of

Ten Conservation Measures in the Meat Industry

Title

1. High Pressure

Return on

Boilers

2. Heat Recovery American Meat Packing

from Conden-

sate Return \&

Flash Steam

3. Whole Blood

Processing

4. Recovered

Refrigeration

Waste Heat

5. Continuous

Rendering

6. Electric

Stimulation

of Beef

7. Preheating

Process

Water with

Recovered

Refrigeration

Waste Heat

8. Continuous

Rendering

9. Microcomputer

Control

Systems

10. Housekeeping

Seatt le Rendering

Armour Food Company

Swift \& Company

North Georgia Render-

ing

Sam Kane Beef Processors

Armour Food Company

Seatt le Rendering

Land O'Lakes

Oscar Mayer
Energy Savings Investment

Btu/yr $\times 10^{9} \quad$ Thousand $\$$

18.9

30

14

5

8.5

250

4

82

3.9

550

6.3

190

4

79

14

300

5.1

43

268 
To obtain more information about these and other energy-conserving methods, please write or call the companies identified in this report or Mary Corrigan or William Sonnett at the U.S. Department of Energy, Office of Industrial Programs, Forrestal Building, Washington, D.C., 20585, (202/252-2075). 
i. CONSERVATION MEASURE: Continuous Rendering

SNERAI INFORMATION

Company Name and Address Seattle Rendering Works

PO Box 58368

Seatt1e, WA 98188

Telephone: (206) 243-7387

Employee Contact: Wes Benefiel

Company President

Plant Location: Seattle, Washington

\section{INTRODUCTION/BACKGROUND}

The rendering industry produces 011 , grease, tallow, and meal from animal and manine slaughter-house scraps. Production has remained stable in the last few years, but the number of plants has decreased significantly. This trend should continue into the next few years as we11. Within the industry there are independent renderers as well as "captive" renderers. Captive renderers are those owned and operated by slaughtering and meat packing companies, Due to their more ensured supply of raw materials, captive renderers will probably gain a larger share of the market in years to come.

In 1979, production for the rendering industry was approximately 15 billion pounds (Casper, 1977). It took 31.3 trillion Btu's of energy, nearly 2100 Biu's per pound of product, to achieve this production figure, making the rendering industry one of the largest energy consumers in the food industry (U.S. Department of Commerce, 1981). Although products from marine sources accounted for just $7 \%$ of the total production figure, they accounted for nearly $25 \%$ of the energy consumed by the industry. This is because the marine scraps contain $80 \%$ water that must be removed, whereas the water content is only $50 \%$ for animal scraps. Rendering is a very energy-intensive business, with 20 to $25 \%$ of the operating costs of a company going to the purchase of fuel and electricity. This energy can be broken down into intermediate uses, as shown in the following table (Casper, 1977).

$\frac{\text { Intermediate Uses of Energy in the Rendering Industry }}{\text { (in percent) }}$

$\begin{array}{lr}\text { Boiler Use } & 81 \\ \text { Direct Use } & 11 \\ \text { Electrical Inputs } & \frac{8}{100} \\ \text { Total } & \end{array}$


It is evident from the table that boiler use is the largest energy consumer.: a rendering plant. Either natural gas or fuel oil is the source of energy for the boiler, with nearly an equal amount of each used industry wide. The following table shows the end-use patterns of this boiler energy in the rendering industry (Casper, 1977).

\begin{tabular}{cc} 
Energy End-Use Activity for Boiler Fuel \\
\hline \multicolumn{2}{c}{ (in percent) } \\
Cooking and Evaporating & 46 \\
Boiler Losses & 26 \\
Heat Boiler Feed Water & 14 \\
Hot Water for Cleaning & 5 \\
Drying (to make meal) & 3 \\
Space Heating & 3 \\
Other Total & 3
\end{tabular}

Since cooking and evaporating constitute such a large portion of the energy consumed in the rendering process, most plants are pursuing ways to reduce energy usage in this area. The most common ways in practice today are (CENTEC Corporation, 1980):

1. continuous rendering

2. insulation of tanks and vats

3. heat recovery of cooker vapors.

This case study examines the continuous rendering process used by Seattle Rendering Works. Faced with environmental pollution problems in 1977 , the company replaced its entire antiquated process line. During the renovation, in an attempt to save energy and to increase production, a continuous cooker was installed where a batch cooker had previously been used.

Seattle Rendering is a privately owned plant that uses meat and fish scraps to produce meat and fish meal, meat fat, and fish $0 i 1$. Nearly $50 \%$ of the feed at Seattle Rendering is fish scraps, which contain approximately $80 \%$ water. This volume of fish scraps is much greater than the industry average. The rendering plant is located in a fishing area, where the concentration of fish scraps is naturally higher. Because fish scraps contain more water than do meat scraps, 
more energy is required to produce a pound of product than is typical for the rest of the rendering industry.

\section{CONSERVATION MEASURE}

Rendering is the most energy-intensive operation in the entire meat processing industry. Feed materials such as animal and fish scraps are rendered to produce oil, grease, tallow, and meal. Rendering is the breaking down of animal and fish cells by mechanical and thermal action, thereby allowing the separation of raw fat from the cellular material. The mechanical action is created by reducing the size of the scraps with a grinder, while the thermal action is created by a cooker. The thermal side of rendering requires great amounts of energy to boil off the water contained in the scraps being rendered. As mentioned earlier, animal scraps contain 50\% and fish scraps contain $80 \%$ water, all of which must be removed.

Most rendering plants in operation today employ batch processes. If the plant is not an integrated part of a meat or fish processing plant, as is the case with Seattle Rendering, the scraps are usually hauled by truck and dumped into scrap receiving bins. Most plants have separate bins for the animal and fish scraps so that the type of feed, and therefore the type of product, can be controlled. The scraps are screw-conveyed out of the bins and sent through an electromagnet to remove ferrous metal inpurities. This same conveying system then moves the scraps through an electrically powered grinder, where they are reduced in size to less than one cubic-inch. The next step in line is the cooker, which is usually a cylindrical vessel with an outside steam jacket used for heating purposes. Since this is a batch process, the cooker must go through the "load-cook-unload" cycle for each group of scraps processed. The cooker is agitated to keep the contents well mixed so that the heat transferred at the outside wall is dispersed throughout the entire cooker. When the scraps are finished cooking, the entire feed has been reduced to slurry form. Free fat is skimmed off the top, and the residue is pumped to a fat press to make meal. The free fat is kept in a storage tank at a temperature just high enough to keep it in the liquid form, whereas the meal is ground into a powder after cooling and is stored in a tank without temperature control. These tanks are located outside of the process line building so that the trucks that transport 
the plant product can be easily filled. The entire process flow is shown in Figure 1.1 .

With the rising costs of energy in recent years, there has been a strong move to continuous rendering operations. In addition to being more energy efficient, continuous rendering supposedly reduces labor requirements, improves product quality, requires less space, and provides easier cleanup. The process in continuous rendering is essentially the same as in batch rendering, except for the cooker. A continuous cooker receives a steady charge of reduced scraps from the grinder and discharges a steady flow of products. A side view and cross-section of a continuous cooker are shown in Figure 1.2. The cooker is a fixed drum, with extensions attached to a rotating shaft in the center of the drum. These extensions mix the cooker contents to achieve better heat transfer, as well as move the scraps down the length of the drum where they become a slurry at the exit end. In a continuous cooker the steam used for cooking and evaporating is supplied to the inside of the rotating shaft, the hollow core of the agitator extensions, and the outside steam jacket. The material being rendered is totally surrounded by a heated surface, which means that heat transfer is more efficient and less heat is lost to the environment. Less steam is therefore consumed by the continuous process than by the batch process. Continuous cookers are applicable to most rendering plants, and may be used in numerous other cooling processes throughout industry.

\section{PLANT PROCESS MODIFICATIONS}

A standard 1000-hp, water-tube boiler is used at Seattle Rendering to generate steam. A water-tube boiler was chosen over a fire-tube boiler because of the high steam requirements in a rendering plant. The boiler is fired by natural gas, and the steam generated is used primarily in the cooker. Before modification, the batch process operated in the manner described in the previous section with 20 million pounds of scraps being processed per year.

In 1977, the rendering plant was completely rebuilt and, during this process, was converted to a continuous rendering operation. This conversion to a continuous operation was made possible with the installation of a continuous cooker. Two views of the continuous cooker installed at Seattle Rendering are shown in Figure 1.2. Due to the energy efficiency of the continuous cooker, 


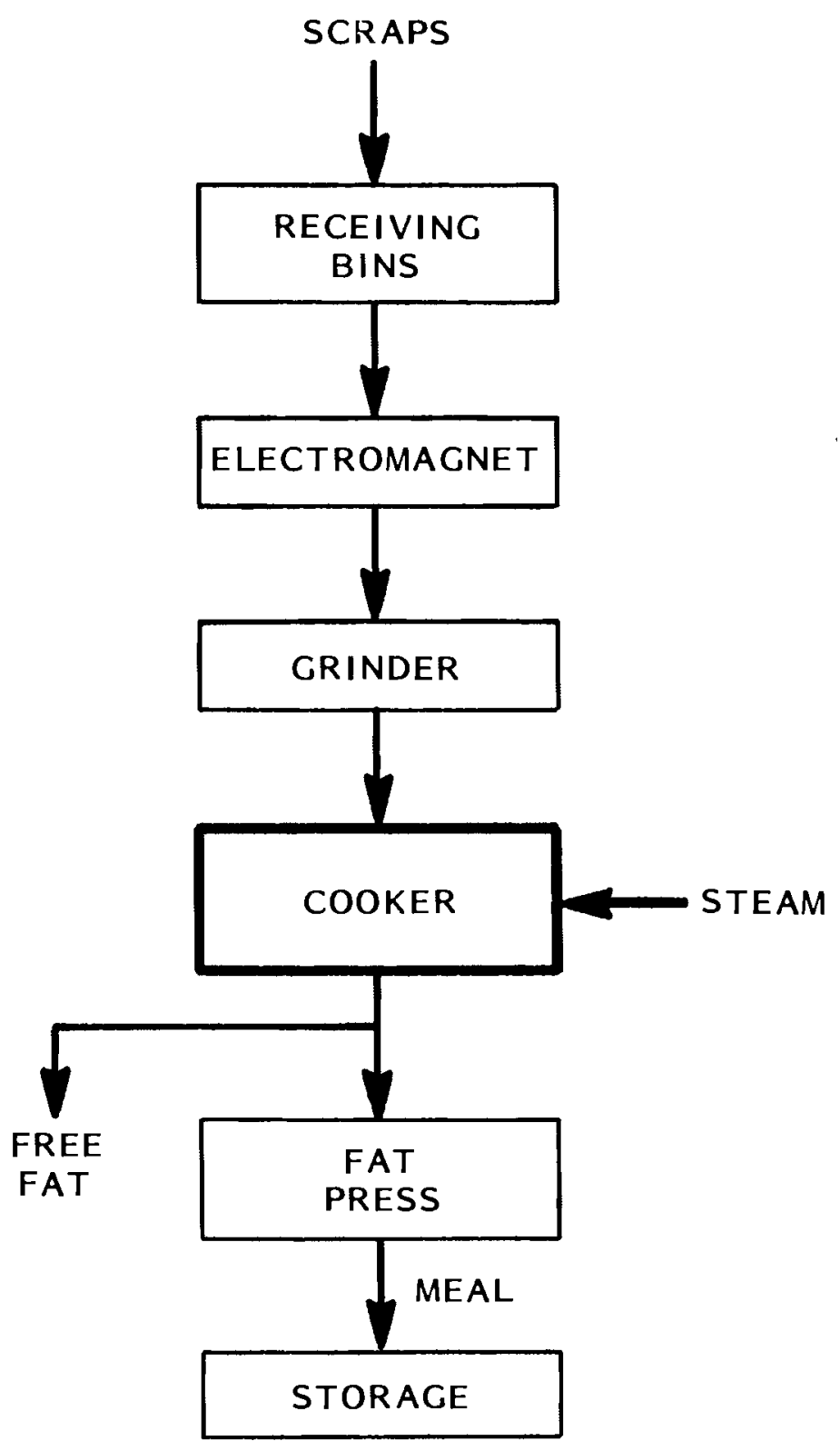

FIGURE 1.1. Process Flowsheet 


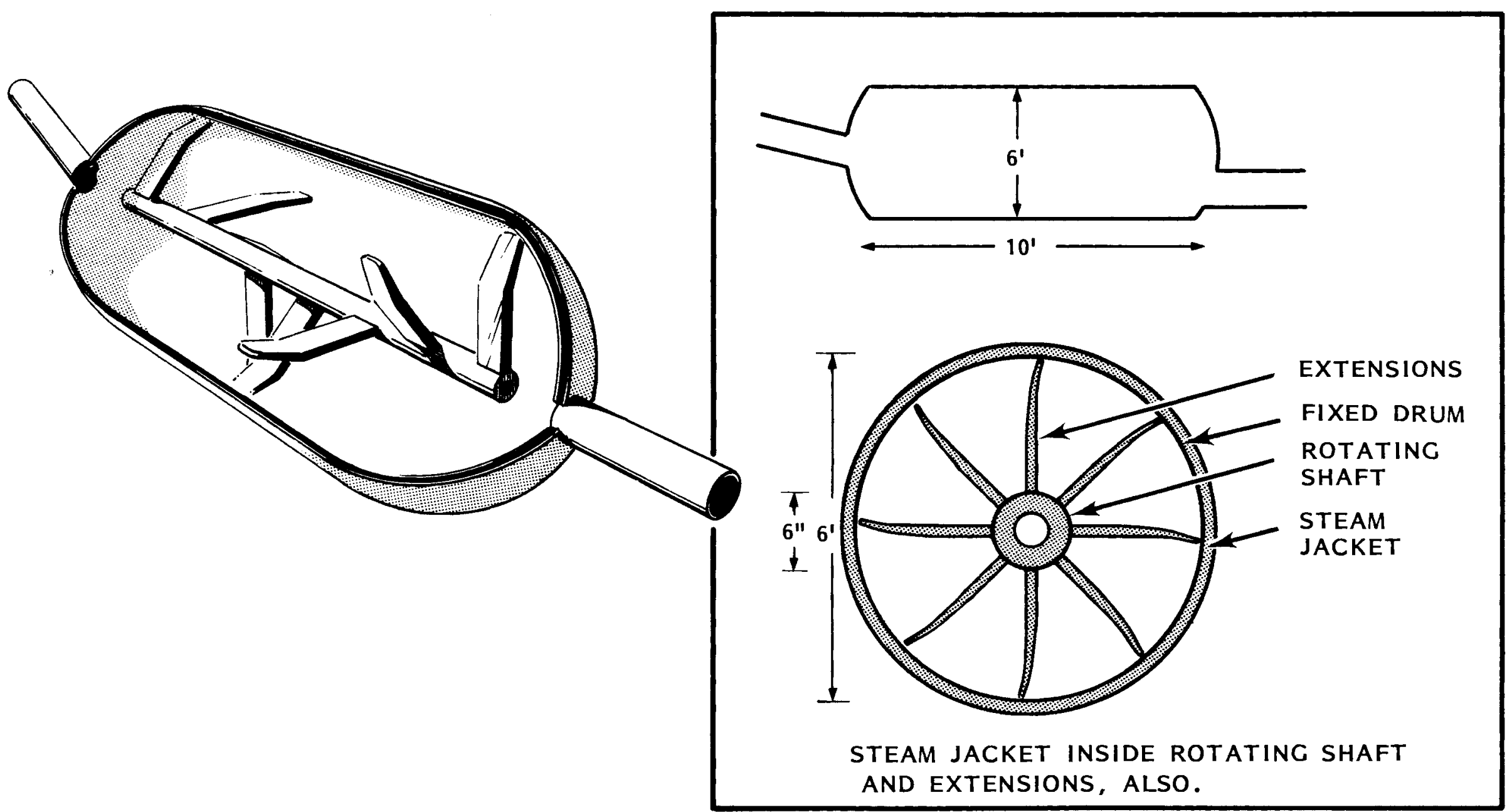

FIGURE 1.2. Side View and Cross Section of Continuous Cooker 
significantly less gas was consumed per pound of product. In addition, plant capacity nearly tripled after the modification, reaching nearly 55 million pounds of processed scraps per year.

\section{ENERGY SAVINGS}

Before the process was modified, the plant handled approximately 20 million pounds of scraps per year and had a fuel bill of $\$ 8000$ per month. All of the fuel was used in the boiler to generate steam, most of which was used in the batch cooker. When Seattle Rendering was paying $\$ 2.10$ per million Btu's for natural gas in 1977 , the system was using

$$
\begin{array}{c|c|c|c}
\$ 8000 & 12 \text { month } & 10^{6} \text { Btu } & \text { year } \\
\hline \text { month } & \text { year } & \$ 2.10 & \begin{array}{c}
20 \times 10^{6} 1 \mathrm{~b} \\
\text { scrap processed }
\end{array}
\end{array}
$$

After the modification, the plant could process nearly 55 million pounds of scraps per year. This increased production pushed the fue 1 bill to $\$ 19,500$ per month, which meant that the system was using

\begin{tabular}{|c|c|c|c|c|}
\hline$\$ 19,500$ & 12 month & $10^{6} \mathrm{Btu}$ & year & \\
\hline month & year & $\$ 2.10$ & $\begin{array}{l}55 \times 10^{6} \text { scrap } \\
\text { processed }\end{array}$ & $\begin{array}{l}\text { lb scrap } \\
\text { processed }\end{array}$ \\
\hline
\end{tabular}

The energy savings (on a per pound basis) associated with the continuous cooker is shown in the following table.

\section{Energy Savings with Continuous Cooker}

\begin{tabular}{|c|c|c|}
\hline & $\begin{array}{c}\text { Gas Use } \\
\text { (Btu/lb Scrap) }\end{array}$ & $\begin{array}{c}\text { Electric Power Use } \\
\text { (Btu/1b scrap) }\end{array}$ \\
\hline Batch & 2286 & 20.0 \\
\hline Continuous & 2026 & 20.9 \\
\hline Savings & 260 & $\overline{-0.9}$ \\
\hline
\end{tabular}

A gas savings of over $11 \%$ was realized, whereas electrical power usage rose slightly. This gas consumption savings is seen in the decline from 2286 to 2026 Btu/lb needed to process the scraps after the continuous cooker was installed. The increase in electrical power used was insignificant compared to the natural gas consumption and had little economic effect. 
For the increased production figure, the dollar savings from the continuous cooker at the time of installation were:

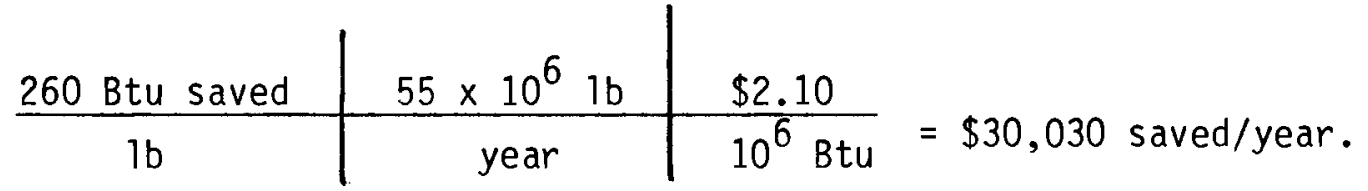

Currently, Seattle Rendering pays $\$ 4.50$ per million Btu's for natural gas.

This would mean a savings today of:

\begin{tabular}{|c|c|c|c|}
\hline 260 Btu saved & $55 \times 10^{6} 1 \mathrm{~b}$ & $\$ 4.50$ & \\
\hline $1 b$ & year & $10^{6} \mathrm{Btu}$ & $=\$ 64,350$ saved $/$ year. \\
\hline
\end{tabular}

DECISION PROCESS

The Environmental Protection Agency (EPA) required that Seattle Rendering either reduce the odor problem associated with its old process or close the plant. Since the existing equipment could not be modified to correct the pollution problem, Seattle Rendering was forced to replace its entire process line. Most of the old equipment was replaced with newer, more efficient models of the same type, but the batch cooker was replaced with a continuous cooker. The owners believed that the increased capacity and energy savings obtained with the continuous cooker were well worth the additional cost.

In 1977, the entire process line and building to house it were installed at a total capital cost of $\$ 1.6$ million. The cost of the continuous cooker alone was $\$ 300,000$, whereas a new batch cooker comparable to the old one was valued at $\$ 150,000$. In the case of Seattle Rendering, the choice was whether to install a batch or a continuous cooker. Based on energy savings from the continuous cooker in 1977, the payback on the incremental cost of the continuous cooker over the batch cooker was:

$$
\frac{\$ 150,000 \text { year }}{\$ 30,030}=5.0 \text { years. }
$$

This figure is deceiving because it is based only on the energy savings from the continuous cooker. The tripled capacity and better product quality of the continuous cooker brought in more revenues for the company, which meant that the actual payback period was much less. Natural gas prices have more than doubled since 1977, but the cost of a continuous cooker has risen only 
moderately. This makes the installation of a continuous cooker even more attractive today than it was then.

Because of the extensive remodeling of the plant, it took one year to remove the old process line and install the new line and associated building. Much less downtime would be required to install a continuous cooker, however. The installation could be scheduled during a low production period for the plant to lessen the downtime effect.

After the continuous process line was installed, labor costs at the plant decreased and maintenance costs increased, with the net effect being a slight decrease in overall operations and maintenance costs. Plant capacity nearly tripled with the continuous process, far exceeding the increased production Seattle Rendering had anticipated. Another unforeseen benefit of the process was the improved product quality, which meant a higher selling price for the company's goods.

The success of the continuous cooker led Seattle Rendering to seek other ways of conserving energy used in cooking and evaporating. As a result, a wasteheat recovery system for the cooker vapors will be implemented in 1982 at a cost of $\$ 900,000$ and at an expected gas savings of $40 \%$ for the boiler.

\section{REFERENCES}

Casper, M. E. ed. 1977. Energy-Saving Techniques for the Food Industry. Noyes Data Corporation, Park Ridge, New Jersey.

CENTEC Corporation. Energy Conservation and Cost Benefits in the Dairy Industry. Fort Lauderdale, Florida. (Draft Report)

U.S. Department of Commerce. 1981. "Fuels and Electric Energy Consumed," 1978 Annual Survey of Manufacturers. M78(AS)-4.1, Bureau of Census, Washington, D.C. 
2. CONSERVATION MEASURE: High-Pressure Return on Boiler

GENERAL INFORMATION

Company Name and Address:

Seattle Rendering Works

P0 Box 58368

Seatt le, WA 98188

Telephone: (206) 243-7387

Employee Contact:

Wes Benefiel

Company President

Technical Consultant: Martin Bosler

\% Bosler Energy Systems, Inc.

14211 N.E. 193rd Place

Woodinville, WA 98072

Telephone: (206) 481-4747

Plant Location:

Seatt le, Washington

\section{CONSERVATION MEASURE}

In an effort to reduce the amount of fuel required to heat boiler feed water, Seattle Rendering installed a high-pressure return system on their boiler in 1979. This system would retain the fluid and, therefore, the heat normally lost through flashing when the steam condensate hit the atmospheric pressure of the flash drum. The prospect for savings is good in this area, since $14 \%$ of all boiler fuels are used to heat boiler feed water.

Most rendering plants operate with an "open" system, which means that the condensed steam is exposed to the atmosphere, thereby causing flashing to occur. A typical setup is shown in Figure 2.1. In this system, saturated steam at an elevated pressure is formed in the boiler and sent to the cooker to heat the scraps. The steam that condenses after serving its heating purpose is removed by steam traps. These traps have a fixed diameter orifice and will let only a limited amount of condensate through at a time. Noncondensable gases, such as air and those that form from the decomposition of carbonates in the boiler feed water, usually don't make it through the steam traps due to this "backing up" of the condensate. These gases, therefore, remain in the cooker, forming pockets of insulation that greatly restrict heat transfer within the cooker. Removed condensate is then sent to a flash drum operating at atmospheric pressure. When the condensate hits this reduced pressure, 
vaporization (or "flashing") of some of the liquid occurs. The amount of flashing increases as the operating pressure of the system increases. For example, a system operating under a pressure of 100 psig will lose $13 \%$ of its condensate to flashing, while a system at 300 psig will lose $22 \%$ (Kewanee Boiler Corporation, 1981). This lost condensate water must be replaced with new make-up water, which is normally at $50^{\circ} \mathrm{F}-60^{\circ} \mathrm{F}$. In other words, we are replacing boiling water that is lost through flashing with cold make-up water. The water returned to the boiler is now significantly below its boiling point, which means that the fuel burned is used both to heat the water and to supply the heat of vaporization needed to cause the phase change to steam. This is why heating boiler feed water comprises such a significant share of the energy used in a boiler.

Many rendering plants are now moving to "closed" systems, i.e., ones in which the returned steam condensate is never exposed to atmospheric conditions. A high-pressure return system is a method of creating this closed effect. This system is shown in Figure 2.2. A closed system prevents the flashing that occurs in the previously mentioned process, which means that the boiler feed water is returned to the boiler at a much higher temperature and pressure. This results in a significant energy savings, since the amount of fuel needed to heat the boiler feed water is drastically reduced. The closed system also allows for the removal of the noncondensable gases that build up in the cooker of the open system. The increased heat transfer made possible by their removal results in increased cooker capacity for the plant.

As before, saturated steam at an elevated pressure is formed in the boiler and sent to the cooker. However, in this system, the steam traps are replaced with variable-orifice discharge modules (VODMs). The uncondensed steam, noncondensable gas, and condensate from the cooker enter the VODMs, where the steam and gases are removed out of the top and the condensate is removed out of the bottom. Since the orifice of the VODMs varies with system conditions, virtually no backing up of the noncondensable gases occurs, thereby increasing the heat transfer in the cooker. Another advantage of the VOUMs is that they have a seven-gallon storage tank for the condensate. The level in each tank is pneumatically controlled so that the flow of returned condensate is more 
uniform. Both streams from the VODMs enter the high-pressure receiver (HPR), which operates at a slightly lower pressure than that of the cooker so that a means of transport is created. The steam and gases that collect in the upper regions of the HPR are sent to the make-up water preheater. Their heat content is used to heat the make-up water; the gases are subsequently removed through the vent. This preheated make-up water is then pumped to the HPR, where it joins the returned condensate. Together, they form the boiler feed water that is returned to the boiler at a temperature and pressure near that of the exit boiler steam. Thus, only the heat of vaporization must be supplied to generate the steam (Kewanee Boiler Corporation, 1981).

The use of these high-pressure return systems is in no way limited to the rendering process. They can be used in any process that uses steam as a heating medium, but are most applicable to processes that use large quantities of steam at pressures greater than 50 pounds. High-pressure return units are now used fairly extensively in the meat packing, rubber, textile, and food processing industries. Their use should continue to grow in these areas in the years to come, as well as enter new markets. These units are quite compact, and are easily retrofitted to most existing systems. The required equipment and piping can be installed in less than a week and should last the life of the boiler.

\section{PLANT PROCESS MODIFICATION}

A standard 1000-hp, water-tube boiler is used at Seattle Rendering to generate steam. A water-tube boiler was chosen over a fire-tube boiler because of the high steam requirements in a rendering plant. The boiler is fired by natural gas, and the steam generated is used primarily in the cooker.

Before modification, the plant operated in the open system mode (described earlier and shown in Figure 2.1). Saturated steam at 140 pounds was generated at the boiler and sent to the cooker. The condensate from the steam traps then flowed to the flash drum, which was operated under atmospheric pressure. At a system pressure of 140 pounds, nearly $16 \%$ of the returned condensate was lost to flashing. The remaining condensate was mixed with $60^{\circ} \mathrm{F}$ make-up water and sent to the boiler at approximately $160^{\circ} \mathrm{F}$. Plant capacity was 55 million pounds of scraps processed per year at that time. 


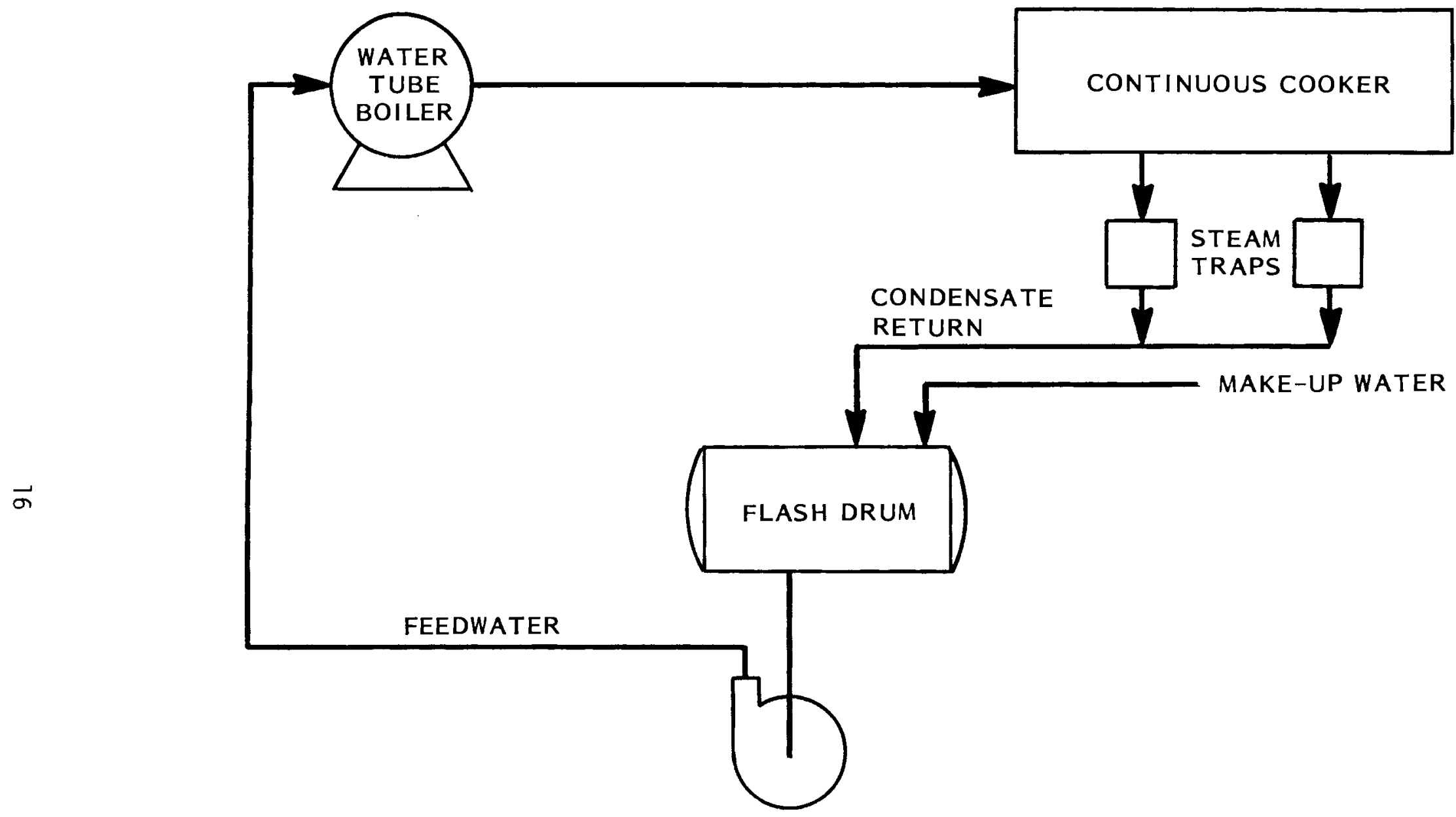

FIGURE 2.1. System Before High-Pressure Return on Boiler 
In 1979, Seattle Rendering converted to the closed-system mode by installing a high-pressure return unit on its boiler (see Figure 2.2). Saturated steam at 140 pounds was again generated at the boiler and sent to the cooker. In this case, however, the condensate from the VODMs flowed to a high-pressure receiver. This receiver was operated at 120 pounds so as to establish enough of a pressure drop to move the gases and condensate from the cooker. This increased pressure also prevented the condensate from flashing. The uncondensed steam and noncondensable gases contained in the receiver were routed to a preheater, where they heated the make-up water and exited through a vent. This preheated water was pumped to the receiver, where it joined the condensate to make up the boiler feed water, which was returned at nearly 140 pounds pressure and at $330^{\circ} \mathrm{F}$ to $350^{\circ} \mathrm{F}$. Due to the increased heat transfer made possible by the removal of the noncondensable qases, plant capacity increased to 62 million pounds of scraps processed per year. The higher pressure and temperature of the boiler feed water also caused a decline in the gas consumption per pound of product.

\section{ENERGY SAVINGS}

Before the high-pressure return unit was installed, the plant processed approximately 55 million pounds of scraps per vear and had a fuel bill of $\$ 26,000$ per month. All of this fuel was used in the boiler to generate steam, with a majority of the steam used in the continuous cooker. When Seattle Rendering was paying $\$ 2.80$ per million Btu's for natural gas in 1979 , the process was using:

\begin{tabular}{c|c|c|c}
$\$ 26,000$ & 12 months & $10^{6} \mathrm{Btu}$ & \\
\hline month & year & $\$ 2.80$ & $\begin{array}{l}55 \times 10^{6} 1 \mathrm{~b} \text { scrap } \\
\text { processed }\end{array}$
\end{tabular}$=\frac{2026 \text { Btu }}{1 \mathrm{~b} \text { scrap processed }}$

After the modification, plant capacity increased to 62 million pounds of scraps per year. Even with the increased production rate, the fue 1 bill dropped to $\$ 24,900$ per month. This meant that the system was using:

\begin{tabular}{c|c|c|c}
$\$ 24,900$ & 12 months & $10^{6} \mathrm{Btu}$ & \\
\hline month & year & $\$ 2.80$ & $\begin{array}{l}62 \times 10^{6} 1 \mathrm{~b} \text { scrap } \\
\text { processed }\end{array}$
\end{tabular}$=\frac{1721 \mathrm{Btu}}{1 \mathrm{~b} \text { scrap processed }}$




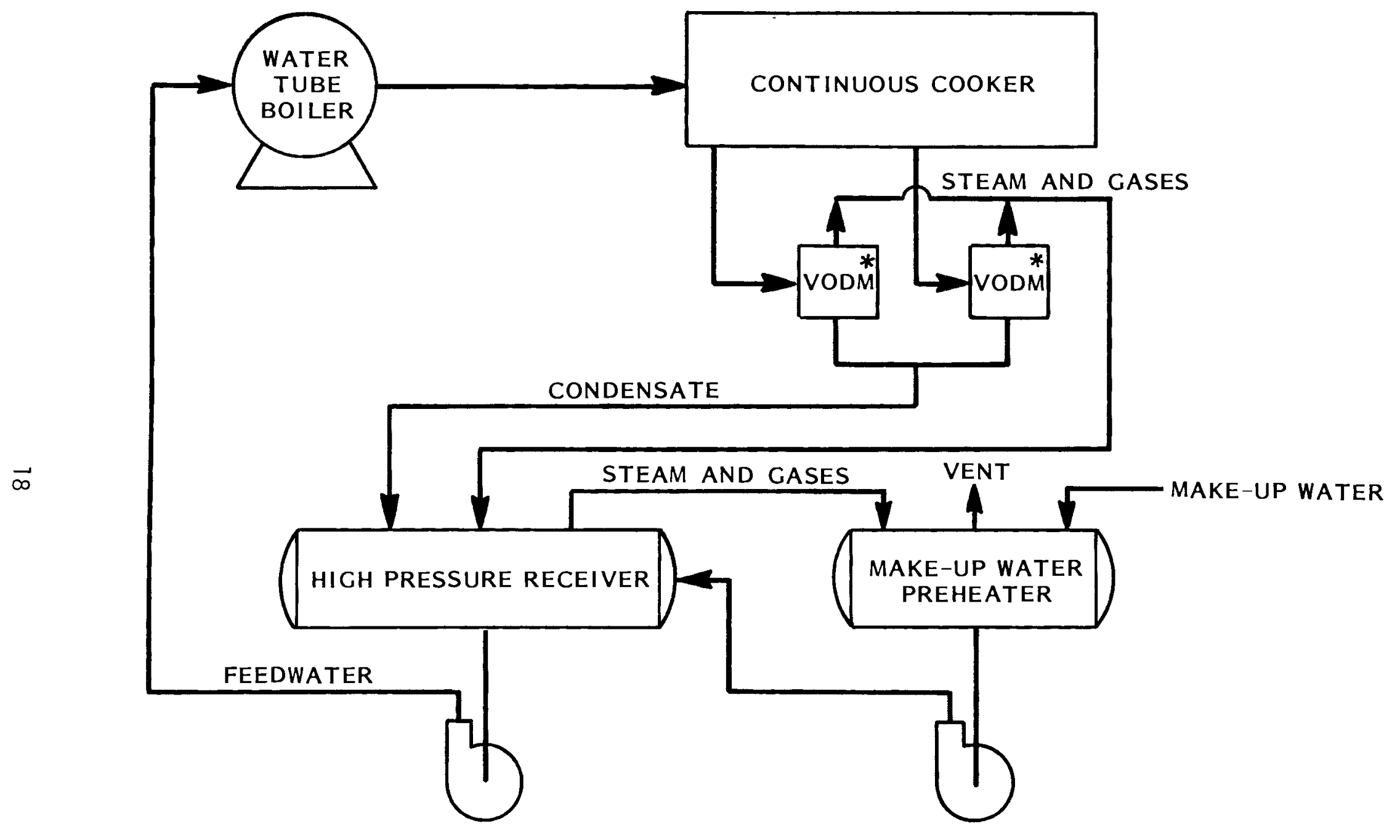

* variable orifice discharge module

FIGURE 2.2. System After High-Pressure Return on Boiler 
The energy savings (on a per-pound basis) resulting from the installation of the high-pressure return system is shown in the following table.

\section{Energy Savings From High-Pressure Return on Boiler}

\begin{tabular}{cc} 
Before Modification & $\begin{array}{c}\text { Gas Use } \\
\text { (Btu/lb scrap) }\end{array}$ \\
\cline { 2 - 2 } After Modification & 2026 \\
Savings & $\underline{1721}$ \\
\hline
\end{tabular}

A natural-gas savings of greater than $15 \%$ was realized, while electrical consumption was unaffected. This savings in gas consumption is seen in the decline from 2026 to 1721 Btu/lb to process the scraps after the high-pressure return unit was put in.

For the increased production figure of 62 million pounds per year, the dollar savings from the unit at the time of installation were:

\begin{tabular}{c|c|c}
$305 \mathrm{Btu}$ Saved & $62 \times 10^{6} \mathrm{lb}$ & $\$ 2.80$ \\
\hline $1 \mathrm{~b}$ & year & $10^{6} \mathrm{Btu}$
\end{tabular}$=\$ 52,950 \mathrm{saved} /$ year.

Currently, Seattle Rendering pays $\$ 4.50$ per million Btu's for natural gas. This would mean a savings today of:

$$
\begin{array}{c|c|c}
305 \mathrm{Btu} \text { Saved } & 62 \times 10^{6} \mathrm{lb} & \$ 4.50 \\
\hline \mathrm{lb} & \text { year } & 10^{6} \mathrm{Btu}
\end{array}=\$ 85,100 \mathrm{saved} / \mathrm{year} .
$$

\section{DECISION PROCESS}

In 1979, the entire high-pressure return system was installed at a total capital cost of $\$ 30,000$. With an energy savings of $\$ 52,950 /$ year at that time, the payback period was:

$$
\begin{array}{l|c|c}
\$ 30,000 & \text { year } & 12 \text { months } \\
& \$ 52,950 & \frac{\text { year }}{2}=6.8 \text { months. }
\end{array}
$$

Assuming the high-pressure return unit could be installed in 1982 for $\$ 40,000$, and that a savings of $\$ 85,100 /$ year could be realized, the payback period today would be: 
$\frac{\$ 40,000 \quad \text { year } \quad 12 \text { months }}{\text { year }}=5.6$ months.

In recent years, the price of energy has risen much faster than the price of process equipment. As long as this trend continues, the payback period for such a system will continue to decrease.

The short forecasted payback period for the high-pressure return system made possible by fuel savings, and the increased cooker capacity were the prevalent reasons Seattle Rendering cited for making the decision to install the unit. The anticipated payback period was realized, as seen in the payback period of just 6.8 months based on the fuel savings for the first year. Increased capacity of greater than $10 \%$ was also realized, as the plant went from 55 million to 62 million pounds of scrap processed per year. In addition to these benefits, plant maintenance costs decreased since fewer noncondensable gases were plating-out on the cooker's heating surfaces.

\section{REFERENCES}

Casper, M. E. ed. 1977. Energy-Saving Techniques for the Food Industry. Noyes Data Corporation, Park Ridge, New Jersey.

Kewanee Boiler Corporation. 1981. Zero Flash-Closed Loop Condensate System. 0akland, California.

U.S. Department of Commerce. 1981. "Fuels and Electric Energy Consumed," 1978 Annual Survey of Manufacturers. M78(AS)-4.1, Bureau of Census, Washington, D.C. 
3. CONSERVATION MEASURE: Heat Recovery from Condensate Return and Flash Steam GENERAL INFORMATION

$\begin{array}{ll}\text { Company Name and Address: } & \text { The American Meat Packing Corporation } \\ & 3946 \text { South Normal Avenue } \\ & \text { Chicago, IL 60609 } \\ & \text { Telephone: (312) 538-7000 } \\ \text { Employee Contact: } & \text { Frank Jones } \\ & \text { Plant Engineer } \\ \text { Plant Location: } & \text { Chicago, I1lino is }\end{array}$

INTRODUCTION/BACKGROUND

In 1979, 20.7 billion pounds (live weight) of hogs were slaughtered under federal inspection in the United States. This resulted in the production of 14.7 billion pounds of pork meat (U.S.D.A., 1980). The balance (6 billion pounds) was by-product or waste. The meat packing industry used 71.1 trillion Btu of energy in 1979 (U.S. Department of Commerce, 1981), much of which was consumed by boilers. The balance of the purchased energy was in the form of steam or fuel for direct use. The following table shows the distribution of energy usage in meat packing plants (Casper, 1977).

Energy Use Distribution in Meat Packing Plants

\begin{tabular}{lr} 
Boiler Fuel & 76 \\
Purchased Electricity & 14 \\
Fuel for Direct Use & 8 \\
Purchased Steam & 2 \\
\multicolumn{1}{c}{ Total } & $\frac{2}{100}$
\end{tabular}

Boilers are the major energy users in the meat packing industry. Energy is used to generate steam for several operations within the plant. A summary of boiler steam usage is provided in the following table.

$\frac{\text { Energy End-Use of Boiler Steam in Meat Packing Plants }}{\text { (in percent) }}$

$\begin{array}{lr}\text { Rendering Operations } & 34 \\ \text { Hot-Water Cleanup } & 20 \\ \text { Heat Boiler Feedwater } & 16 \\ \text { Space Heat and Process Steam } & 16 \\ \text { Hot-Water Production } & \underline{14} \\ \quad \text { Total } & 100\end{array}$


The American Meat Packing Corporation's (AMPAC) Chicago plant uses large amounts of steam and hot water for slaughtering and rendering operations. Approximately one-third of the total steam produced is used for rendering; hot water for cleanup throughout the plant uses an additional $20 \%$ of the total steam. The Chicago plant uses 1.45 million pounds of steam per week and 1.54 million gallons of city water per week. City water is used for both steam production and cleanup. This plant uses natural gas to fuel its steam boiler. Thus, reduction in steam usage would result in a direct reduction in natural gas consumption. Several ways for reducing steam consumption and, in turn, boiler fuel consumption can be identified. These include:

1. improve and maintain boiler efficiency;

2. reduce heat losses from boilers;

3. reduce heat losses in distribution systems;

4. reduce steam consumption by recovery of waste heat.

This case evaluates the fourth method, recovery of waste heat, and involves the use of plant condensate and flash steam. These two projects resulted in a reduction in steam used to preheat the boiler feedwater and to heat plant cleanup water.

The American Meat Packing Corporation is a subsidiary of Kane-Miller Corporation. Kane-Miller is a diversified food processor whose operating subsidiaries process and market meats, poultry, and animal by-products, and manufacture or process other food products such as margarine, cheese, fresh prepared foods, bakery products, canned vegetables, and fruit wines. KaneMiller had net sales of approximately $\$ 623$ million and a net income of $\$ 4.9$ million in 1980 (Moody's, 1981). The Chicago plant of AMPAC slaughters and renders 6,000 head of hogs per week. This plant is quite old but has implemented many energy conservation measures in the past, and is currently recovering waste heat from the condensate water and flash steam to conserve energy.

\section{CONSERVATION MEASURE}

The recovery of condensate water and its use as boiler feedwater was facilitated by the addition of condensate return lines and by the proximity of the 
boiler to the rendering operation, which uses about one-third of the plant steam. In addition, the condensate from the steam used to heat the feedwater was also recovered. This results in the return of about $50 \%$ of the condensate to the feedwater tank. It has been estimated that $10 \%$ to $30 \%$ of the amount of fuel used to make steam can be saved by using condensate as boiler feedwater (Reay, 1979).

The second conservation measure is the use of flash steam from the boiler and rendering operations to keep the plant's hot water at $160^{\circ} \mathrm{F}$, which uses approximately $20 \%$ of the total steam produced. The flash steam from the plant is rerouted through a single shell and tube heat exchanger. On one side of the exchange wall is the flashed steam; on the other, hot water. After passing through the heat exchanger, the flash steam is sent to the feedwater tank as condensate. The flash steam is used in both of these technologically simple conservation measures.

\section{PLANT PROCESS MODIFICATIONS}

Both of the conservation measures were begun in the AMPAC Chicago plant in 1980. Before 1980, the condensate water throughout the plant had been trapped and drained into the sewer (Figure 3.1). In 1980, the condensate from the entire plant was routed by installing piping to the feedwater tank (Figure 3.2). The condensate return was 15,000 gallons per day, which reduced the boiler make-up city water by 15,000 gallons per day. After the condensate water was mixed with the feedwater the temperature was $190^{\circ} \mathrm{F}$. Therefore, no steam was needed to heat the feedwater.

Chemical treatment and brine salt for water-softening is needed before the feedwater can be introduced into the boiler. Before installation of the recovery system, 9 lbs/day of water treatment chemicals and 94 lbs/day of brine salt were used. After the condensate return system was installed, the amount of chemicals was reduced to $3 \mathrm{lb} /$ day and brine salt to $73 \mathrm{lb} /$ day. This reduction occcurred because the condensate water was already softened.

Plant records indicated that before 1980, 20,000 1bs/day of steam were used to keep the clean-up water hot (Figure 3.3). This steam came directly off the boiler. The second conservation project involved piping flash steam, pre- 


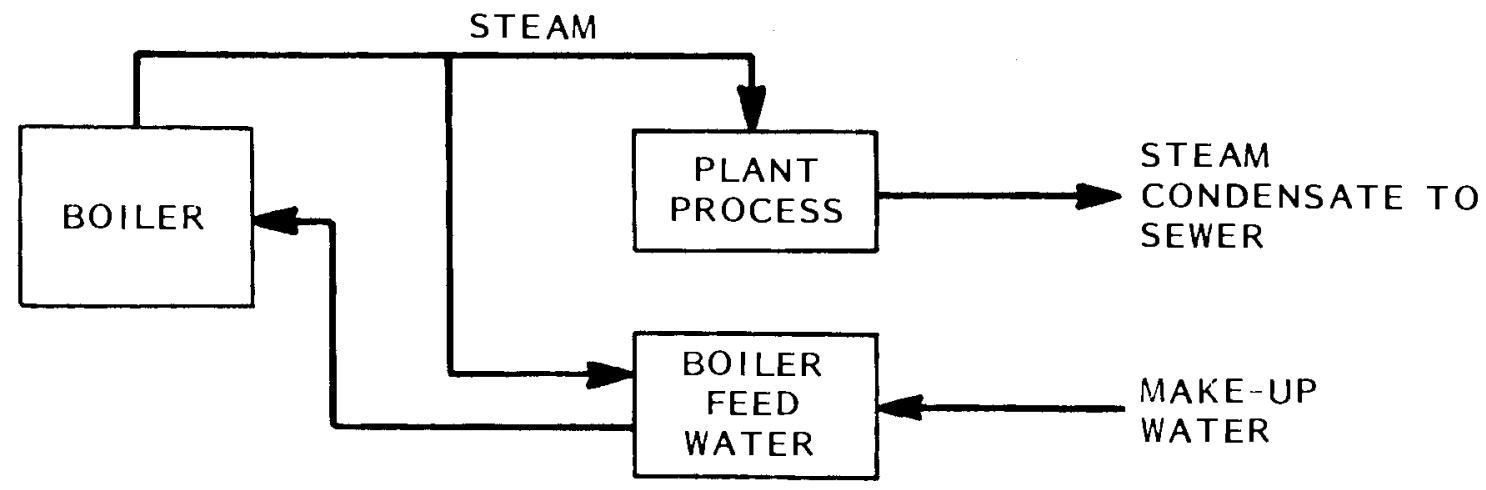

FIGURE 3.1. Heating of Boiler Feedwater Before Modification

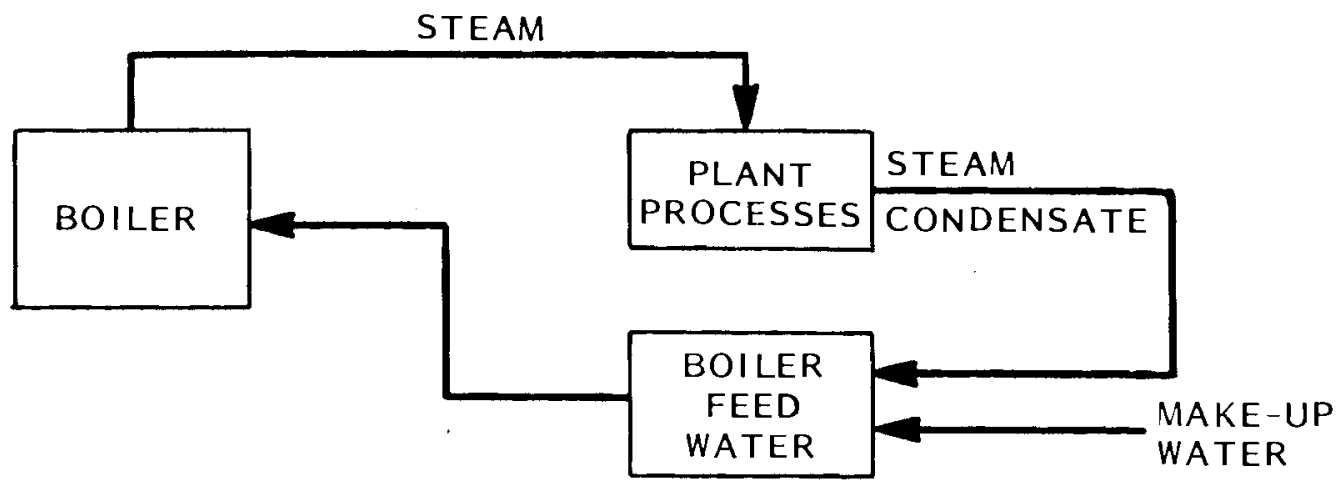

FIGURE 3.2. Steam Condensate Flow and Heating of Boiler Feedwater After Modification 


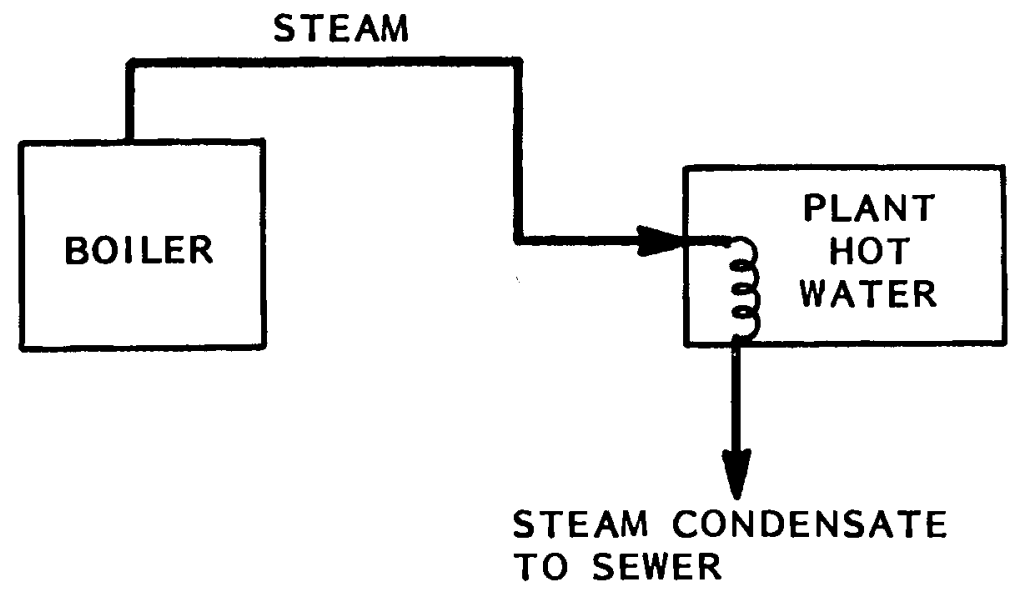

FIGURE 3.3. Heating of Plant Hot Water Before Modification

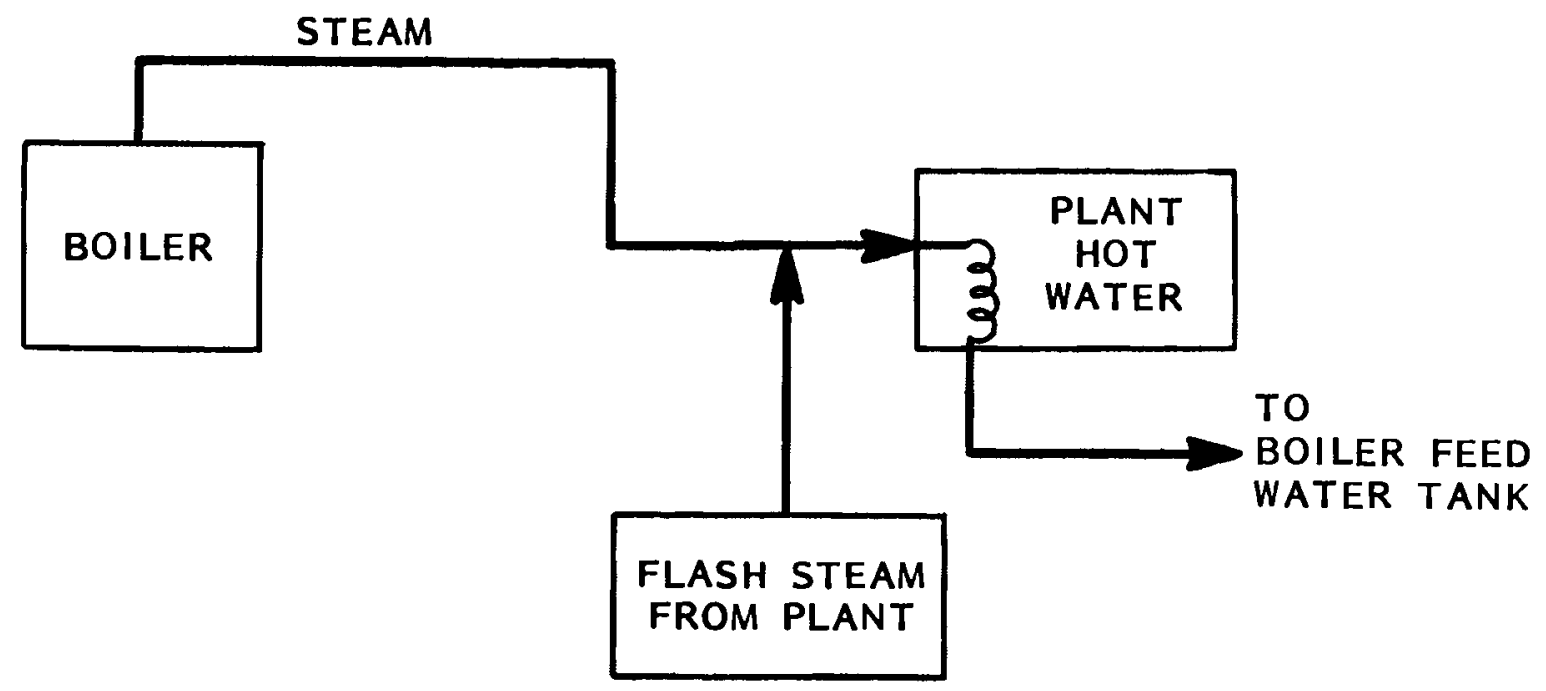

FIGURE 3.4. Flash Steam Flow and Heating of Plant Hot Water After Modification 
viously vented into the atmosphere, through a heat exchanger to keep the plant clean-up water at $160^{\circ} \mathrm{F}$ (Figure 3.4).

\section{ENERGY SAVINGS}

To examine the impact of condensate water use, one must calculate the amount of energy used to heat the boiler make-up water. Before the condensate return system was installed, the make-up water to the boiler feedwater tank averaged 30,000 gallons per day at $60^{\circ} \mathrm{F}$. The water was then heated to $190^{\circ} \mathrm{F}$ before introduction into the boiler. Assuming $90 \%$ thermal efficiency, the energy needed to raise the temperature of one pound of water from $60^{\circ} \mathrm{F}$ to $190^{\circ} \mathrm{F}$ is 144 Btu. Since water at $190^{\circ} \mathrm{F}$ weighs 8.07 pounds per gallon, 242,100 pounds of water was heated per day. Therefore, the total energy needed per day from the steam to heat the feedwater was $242,0001 \mathrm{bs} /$ day $\times 144 \mathrm{Btu} / 1 \mathrm{~b}=3.486 \mathrm{x}$ $10^{7}$ Btu/day.

Natural gas used at the Chicago plant has a heat content of 1026 Btu/cubic foot. Natural gas at the following rate was used to heat the boiler feedwater: $3.486 \times 10^{7} \mathrm{Btu} / \mathrm{day} \times 1 \mathrm{ft}^{3} \mathrm{gas} / 1026 \mathrm{Btu}=34,000 \mathrm{ft}^{3} \mathrm{gas} / \mathrm{day}$.

The condensate return system saved all of the $34.86 \mathrm{million} \mathrm{Btu/day}$ that had been used to heat the boiler feedwater. This translates into 25,408 1b steam/day saved as follows:

$$
\begin{array}{c|c}
3.486 \times 10^{7} \mathrm{Btu} & 1 \text { 1b steam }
\end{array}=25,408 \text { 1b steam } / \text { day }
$$

At the time of installation, the cost per million Btu of natural gas was $\$ 3.30$ at the Chicago plant. The average number of working days is 282 per year. The annual cost savings from the condensate return system are:

$$
\begin{array}{c|c|c}
3.486 \times 10^{7} \text { Btu } & \$ 3.30 & 282 \text { days } \\
\hline \text { day } & 10^{6} \text { Btu } & \text { year }
\end{array}
$$

The savings from the installation of the flash steam heat exchanger were observed from plant records. To examine the impact of the flash steam system, one must calculate the amount of energy used to produce boiler steam. The feedwater to the boiler enters as a saturated liquid at $190^{\circ} \mathrm{F}$ with an 
enthalpy of 158 Btu/lb. The steam exits the boiler at saturated conditions at 100 psia with an enthalpy of 1187 Btu/lb. If the boiler efficiency is $75 \%$, the amount of energy used is 1187-158/0.75 = 1372 Btu per pound of steam produced. Using the gas heat content of $1026 \mathrm{Btu} / \mathrm{ft}^{3}$ of gas, the amount of gas used per pound of steam generated is calculated as $1372 \mathrm{Btu} / 1 \mathrm{~b}$ steam $\times 1 \mathrm{ft}^{3} \mathrm{gas} / 1.026$ Btu $=1.337 \mathrm{ft}^{3}$ gas $/ 1 \mathrm{~b}$ steam. The amount of gas used to keep the plant cleanup water hot is $20,0001 \mathrm{~b}$ steam/day $\times 1.337 \mathrm{ft}^{3}$ gas $/ 1 \mathrm{~b}$ steam $=26,740 \mathrm{ft}^{3}$ gas/day. Steam usage from the boiler to the hot-water tank dropped from 20,000 lbs/day to $8400 \mathrm{lbs} /$ day for a net savings of $11,600 \mathrm{lbs} / \mathrm{day}$. The amount of gas saved was:

$$
\begin{array}{c|c|c|c|}
11,600 \text { lb steam } & 1,372 \mathrm{Btu} & 1 \mathrm{ft}^{3} \mathrm{gas} \\
\hline \text { day } & \text { 1b steam } & 1,026 \mathrm{Btu} & 15,500 \mathrm{ft}^{3} \mathrm{gas} / \mathrm{day} .
\end{array}
$$

This is a savings of $1.6 \mathrm{million}$ Btu/day $\left(15,500 \mathrm{ft}^{3}\right.$ gas $\left.\times 1026 \mathrm{Btu} / \mathrm{ft}^{3} \mathrm{gas}\right)$. The annual cost savings are:

$$
\begin{array}{l|l|l}
1.6 \times 10^{7} \mathrm{Btu} & \$ 3.30 & 282 \text { days } \\
\hline \text { day } & 10^{6} \text { Btu } & \text { year }
\end{array} 14,900 / \text { year. }
$$

The total energy savings associated with these two conservation measures is $\$ 47,300 /$ year. The total capital cost for the two projects is estimated to be about $\$ 5,000$, primarily because the equipment for the modifications was already at the plant. (Capital costs for this project will vary for other sites depending upon distance between process equipment and the boiler.) Most of the equipment was standard items such as pipes, valves, fittings, etc.

\section{DECISION PROCESS}

The two conservation systems, condensate return and flash steam heat exchanger, were installed for energy saving reasons only. These systems were installed in 1980 for a total cost of $\$ 5,000$. In addition to the $\$ 47,300 /$ year in energy savings, the following nonenergy cost savings were achieved by the installation of the two systems.

The use of water treatment chemicals was reduced from $9 \mathrm{lb} /$ day to $31 \mathrm{~b} / \mathrm{day}$, which resulted in a savings of $\$ 9.36 /$ day. Brine salt used for water softening was reduced from 94 1b/day to 73 1bs/day, which saved $\$ 7.98$ a day. A total of 
$\$ 17.34 /$ day or about $\$ 4,900 /$ year was saved on chemical costs.

City water consumption was reduced $15,000 \mathrm{gal} /$ day, which resulted in about $2,000 \mathrm{ft}^{3}$ of water saved per day or $565,000 \mathrm{ft}^{3}$ per year. At a cost of $\$ 0.006 / \mathrm{ft}^{3}$ of water, the annual savings in water was $\$ 3,400$. The total nonenergy cost savings are about $\$ 8,300 /$ year.

The total cost savings were $\$ 56,200 /$ year for both systems. Installation was problem free and no significant drawbacks have been noted with the new system. Because of the low capital cost $(\$ 5,000)$, the payback period was only about one month. This alone was reason to install the systems.

The American Meat Packing Corporation is also considering further energy conservation systems in its Chicago plant. An automatic continuous blow-down system was installed in 1981. This improvement resulted in an annual savings of about $\$ 4,300$. A blow-down heat exchanger that would save about $\$ 3,700 /$ year is also being considered.

\section{REFERENCES}

Casper, M. E., ed. 1977. Energy-Saving Techniques for the Food Industry. Noyes Data Corporation, Park Ridge, New Jersey.

Moody's Investors Services, Inc. 1981. Moody's Industrial Manual. Vo1. 2. New York, New York.

Reay, D. A. 1979. Industrial Energy Conservation. 2nd Edition. Pergamon Press, Inc., Elmsford, New York.

U.S. Department of Agriculture. 1980. Agricultural Statistics 1980. U.S. Government Printing Office, Washington, D.C. 
4. CONTINUOUS MEASURE: Continuous Whole Blood Processing

GENERAL INFORMATION

Company Name and Address: Armour Food Company

Greyhound Tower

Phoenix, AZ 85077

Telephone: (602) 248-4000

Employee Contact: Jerry Michalski

Operations Specialist

Plant Location: $\quad$ St. Joseph, Missouri

\section{INTRODUCTION/BACKGROUND}

In 1979, 20.7 billion pounds (live weight) of hogs were slaughtered under federal inspection in the United States. This resulted in the production of 14.7 billion pounds of pork meat in the United States (U.S.D.A., 1980). Because blood makes up about $3.5 \%$ of the total live weight of a hog, 724 million pounds of hog blood (whole) had to be disposed of in the slaughtering process. The blood must be processed before any part is sent to the sewage system.

The treatment of whole blood in the meat packing industry is considered a rendering operation and is accomplished by thermal drying of the blood. Blood is made up of about $80 \%$ water and $20 \%$ solids or blood meal. Boiler steam is used to concentrate the blood meal to produce a saleable product. The blood meal produced has a protein content of 80 to $90 \%$ and is the richest known source of lysine, an amino acid lacking in most animal feeds and fertilizers (Filstrip, 1976).

The blood meal in whole blood is also concentrated to avoid a major pollution problem and potential fines or increased sewage fees. In the United States most water pollution regulations specify that waste water discharged into municipal sewers must have a pollution load of less than 250 to $300 \mathrm{mg} / 1$ of biological oxygen demand $\left(\mathrm{BOD}_{5}\right)$. (The $\mathrm{BOD}_{5}$ value is the quantity of oxygen necessary during the first five days to decompose the pollutants in waste water at $20^{\circ} \mathrm{C}$ by aerobic biological action.) Sewage waste from slaughterhouses processing whole blood could have a pollution load or $\mathrm{BOO}_{5}$ value as high as 
$250,000 \mathrm{mg} / 1$. Thus, the blood meal is concentrated, separated from the water, and the relatively clean water is disposed of in the sewage system.

The meat packing industry used 71.1 trillion Btu of energy in 1979. Much of this energy was consumed by boilers, the balance was in the form of purchased electricity and steam or fuel for direct use. The following table shows the distribution of energy usage in meat packing plants (Casper, 1977).

\section{Energy Use Distribution In Meat Packing Plants}

(in percent)

$\begin{array}{lr}\text { Boiler Fuel } & 76 \\ \text { Purchased Electricity } & 14 \\ \text { Fuel for Direct Use } & 8 \\ \begin{array}{l}\text { Purchased Steam } \\ \text { Total }\end{array} & \frac{2}{100}\end{array}$

Boilers are the major energy user in the meat packing industry. Fuel is used to generate steam for several operations within the plant. A summary of the uses of boiler steam is provided in the following table.

Energy End-Uses of Boiler Steam in Meat Packing Plants

(in percent)

\begin{tabular}{lr} 
Rendering Operations & 34 \\
Hot-Water Cleanup & 20 \\
Heat Boiler Feedwater & 16 \\
Space Heat and Process Steam & 16 \\
Hot-Water Production & 1.4 \\
\hline & 100
\end{tabular}

Rendering is the most energy-intensive operation in the meat industry, using $34 \%$ of the steam consumed in a meat packing plant. Whole blood drying is only one use of steam in the rendering section of the plant. Energy consumption in the rendering section of a plant can be reduced through: 1) continuous rendering, 2) insulation of tanks and vats, and 3) heat recovery of cooker vapors.

Armour Food Company, a subsidiary of Greyhound Corporation, is a manufacturer and processor of food products and by-products, household goods, pharmaceuticals, and handicraft products. Within the food products group, the by-products 
class includes feed ingredients for livestock and poultry, pelts/hides, animal bones, Dlood, and glands which are sold to chemical, fertilizer, and pharmaceutical manufacturers. In 1980 the by-products class produced revenues of $\$ 93$ million, which accounted for $3 \%$ of the total revenues of Armour Food Co. (Moody's, 1981). The St. Joseph, Missouri, plant is one of nine Armour slaughtering plants in the United States and is also a major processing and distributing plant. Armour Food Co. has long been involved in the field of industrial energy conservation and continues to be an innovator in this area.

\section{CONSERVATION MEASURE}

Thermal drying with a batch cooker system is the conventional method of blood processing. Because of the high concentration of water that must be removed, energy consumption for thermal drying is very high. If the diluted blood contains $80 \%$ water, $97 \%$ of the water must be removed before the blood can become blood meal.

Three methods can be used to remove water: 1) one-step batch drying in a conventional blood dryer to a final water content of $8 \%$ to $10 \%$; 2) coagulating, draining, and possibly pressing batches of blood, and then drying the blood to a water content of $8 \%$ to $10 \%$; and 3 ) continuously drying blood through stages of preheating, coagulation, and separation in a decanter centrifuge that can remove as much as $80 \%$ of the water. Final drying is then completed using a conventional dryer. In Method 1 , all of the water is removed through evaporation whereas, in 2 and 3 , only part of the water is removed through evaporation and some is removed mechanically. Method 3, the continuous method, is under study in this case. The quantity of steam needed for drying is directly proportional to the amount of water evaporated; therefore, less steam is needed in the continuous method since the blood meal is coagulated and separated mechanically in this process. Because the load is less in the continuous method, the dryer can be smaller. The continuous method also allows better control of product losses in the waste liquid. This saves money and helps control the $\mathrm{BOD}_{5}$ or pollution problem. Because of the continuous nature of the operation, less time is required for processing and only partial operator attention is needed to control the equipment. The value of the product is improved via the continuous method because less protein is lost 
through the use of chemicals for coagulation and reduced cooking time. Other benefits of this system include the small space needed to house equipment, the ease of cleaning in place, the reduction of odor because of the sealed system, and the low cost of installation. A number of systems are on the market with comparable operating conditions and cost.

A continuous dryer is used to remove water when sterilization is not required. Continuous dryers can be drum or rotary dryers, ring dryers, fluidized-bed dryers, and spray dryers. Each dryer has its advantages and disadvantages, depending on the type of product desired and the operating conditions.

\section{PLANT PROCESS MODIFICATIONS}

Conventional batch systems, (Figure 4.1) consist of a raw blood storage tank and a large batch dryer. In this system, raw blood is screened to remove foreign objects and then is stored in tanks before being pumped into the batch cooker. The batch cooker reduces the moisture content of the raw blood from $80 \%$ to approximately $10 \%$. Therefore, $87 \%$ of the water must be removed by evaporation using the batch cooker. The blood meal produced has a protein content of $82.2 \%$. Assuming a one-shift operation for the blood drying system for 260 to 270 days/year and a yield of 7.2 lbs of blood per head, the total flow through the process is 42.25 lbs of blood/hour of operation. In this conventional system, approximately $7273 \mathrm{lb} / \mathrm{hr}$ of steam is needed to dry the blood.

Armour Food Company installed a continuous system with the equipment shown in Figure 4.2. The continuous system has three phases of operation:

1. the addition of chemicals to promote separation of blood solids from water and to reduce the $\mathrm{BOD}_{5}$ in effluent;

2. coagulation of blood solids via direct steam addition;

3. mechanical separation of 50 to $60 \%$ of the water in the decanter centrifuge (shown in Figure 4.3).

After centrifuging, the blood solids are dried in a conventional rotary dryer to a $10 \%$ moisture level. The continuous system uses less steam because of the chemical and mechanical separation of the blood solids from water. For example, with the new continuous system, approximately $2900 \mathrm{lb} / \mathrm{hr}$ of steam is 


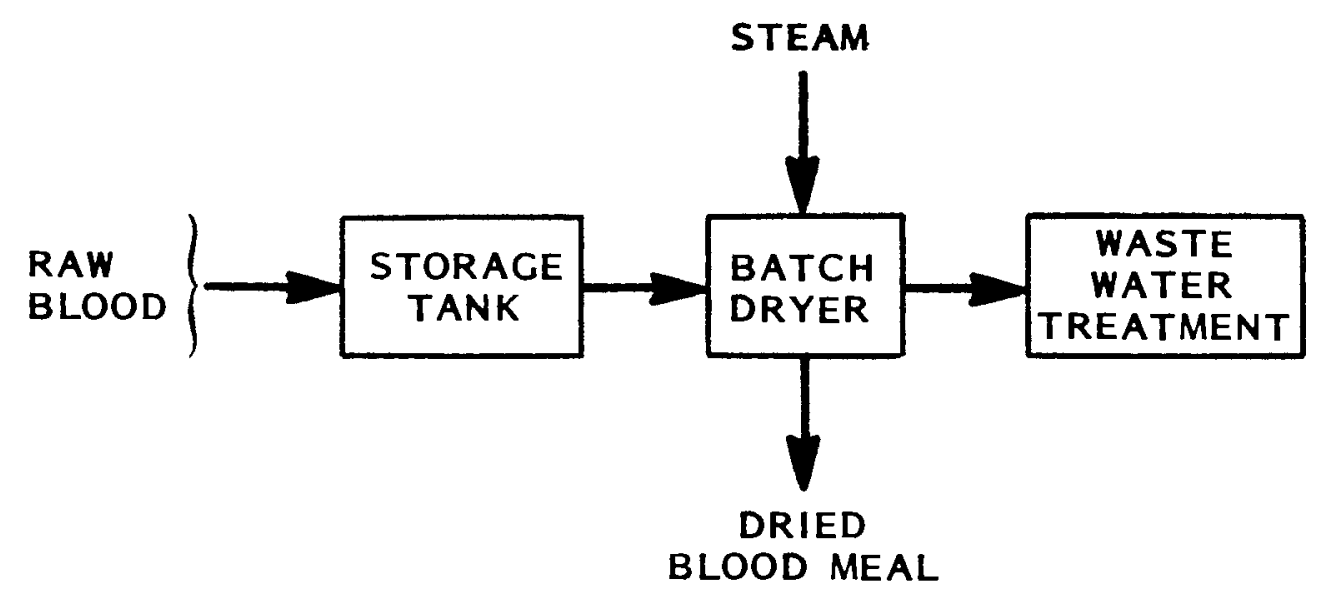

FIGURE 4.1. Conventional Blood Drying

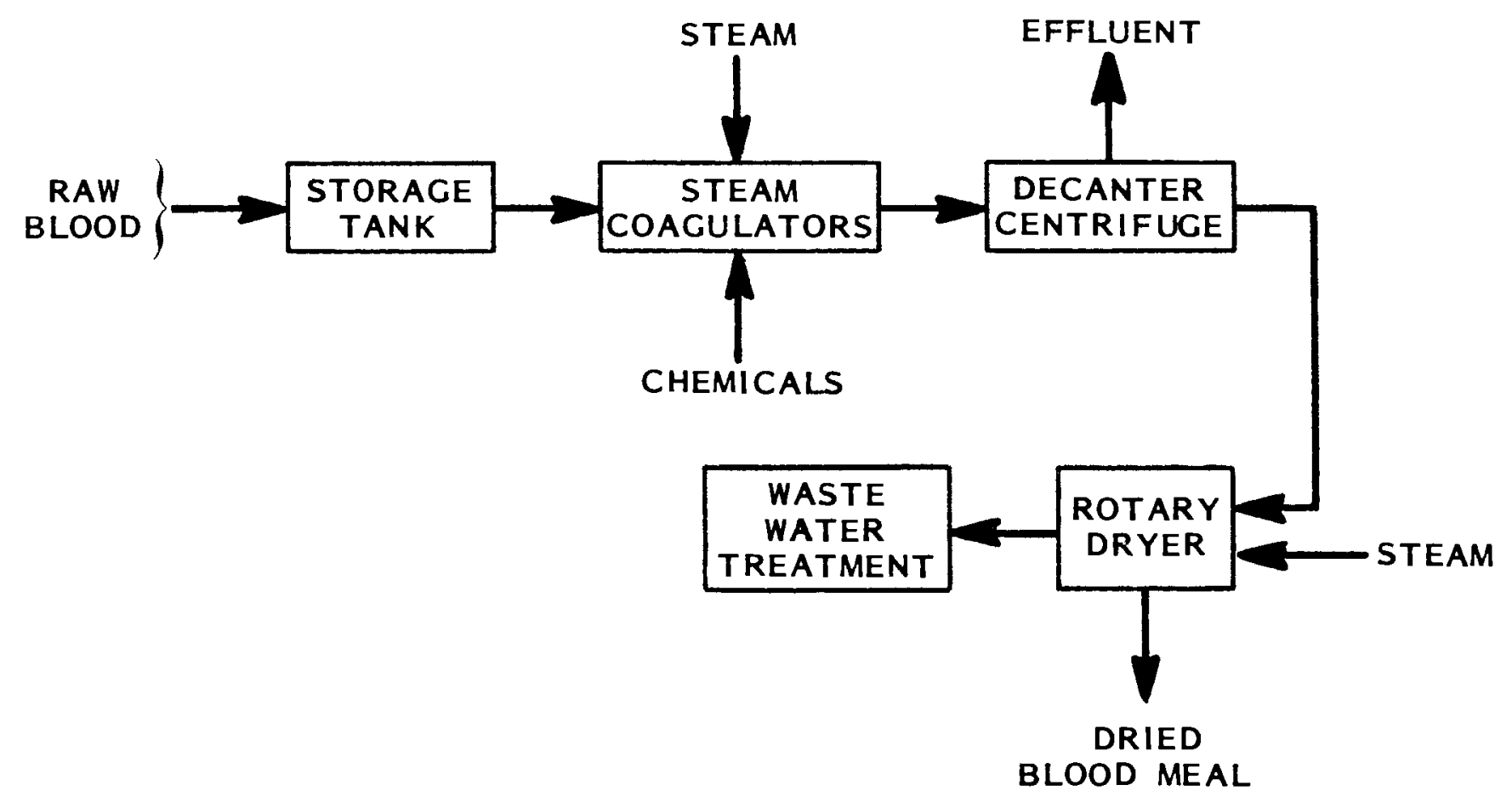

FIGURE 4.2. Continuous Blood Drying 


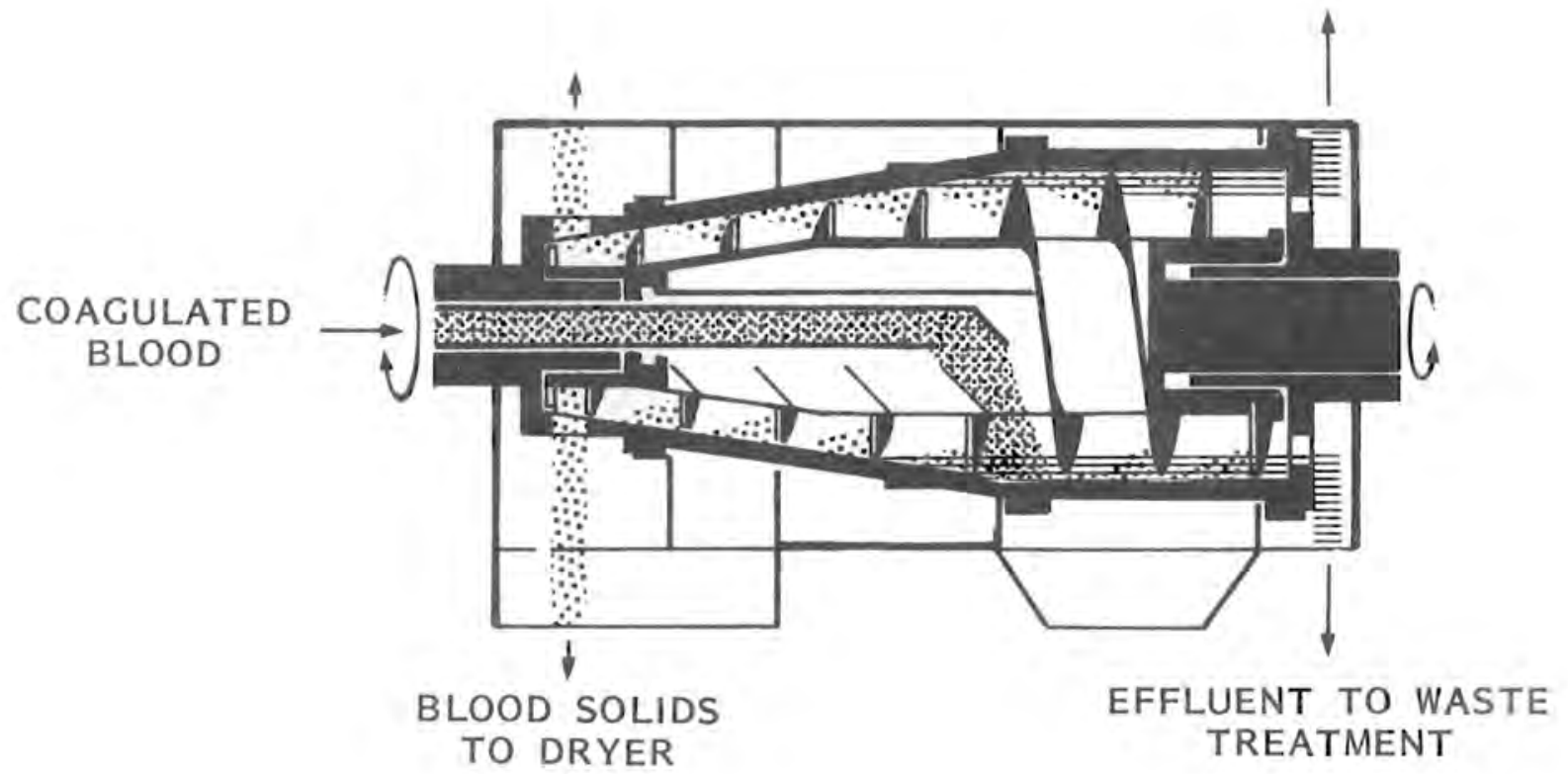

FIGURE 4.3. Decanter Centrifuge 
required to process the same $4225 \mathrm{lb} / \mathrm{hr}$ of blood. The use of chemicals to coagulate the blood solids results in a final protein content of $84.8 \%$ compared to the $82.24 \%$ from conventional batch cookers.

\section{ENERGY SAVINGS}

Based upon data from Armour Food Company, the conventional system of drying blood used $7273 \mathrm{lb} / \mathrm{hr}$ of steam versus approximately $2900 \mathrm{lb} / \mathrm{hr}$ of steam with the continuous system. The energy savings from the new system are, therefore, approximately $4370 \mathrm{lb} / \mathrm{hr}$ of steam. If the plant operates this system on a oneshift basis for about 268 days per year, the energy savings would be 9.4

million 1b/yr of steam. Some electricity savings are also realized but are not included here because they are small compared to the steam savings.

The total cost of the continuous system, including the rotary dryer, was $\$ 250,000$. The continuous system is available in three basic sizes and includes the preheat tank, pumps, coagulator, decanter centrifuge, control panel, and process piping.

The energy cost savings from the reduction in steam usage are calculated as follows:

$$
\begin{array}{c|c|c}
4370 \text { lbs steam saved } & \$ 0.00397 & 2144 \text { hours }
\end{array}=\$ 37,200 / \text { year }
$$

This is based on a cost for steam of about $2 \notin$ per hog with the new system. DECISION PROCESS

The new continuous system was installed primarily to improve product quality and provide energy savings. The St. Joseph, Missouri, Armour plant has used the continuous system since the plant was built, and Armour plans to install another continuous system in its Huron, South Dakota, plant. The payback period for the continuous sytem is 6.7 years, given an initial investment of $\$ 250,000$ and energy savings of $\$ 37,200$ per year. This is a conservative estimate based upon energy savings.

Most of the net savings from the continuous systems are energy cost savings. There are other savings, but most are offset by additional costs. For example, although pickup of processed hair is increased about $11 \%$ (valued at $\$ 215 /$ ton), 
this gain is offset almost completely by a decrease of about $30 \%$ in blood yield, even though the protein content increases by approximately $2.56 \%$. In balance, the new system produces a superior quality product (one having less moisture) and saves energy but has a lower yield of blood meal overall.

Some of the other nonquantitative benefits resulting from the installation of the continuous system are improved odor and airborne material control, labor savings because of the automatic control system, and reduced space requirements for the equipment. Installation was problem free, and no significant drawbacks have been noted with the new system.

\section{REFERENCES}

Casper, M. E. ed. 1977. Energy-Saving Techniques for the Food Industry. Noyes Data Corporation, Park Ridge, New Jersey.

Filstrip, P. 1976. Handbook for the Meat By-Products Industry. Alfa-Laval, Ft. Lee, New Jersey.

Moody's Investors Services, Inc. 1981. Moody's Industrial Manual. Vol. 1. New York, New York.

U.S. Department of Agriculture. 1980. Agricultural Statistics 1980. U.S. Government Printing Office, Washington, D.C.

U.S. Department of Commerce. 1981. "Fuels and Electric Energy Consumed." 1979 Annual Survey of Manufacturers. M79(AS)-4.1, Bureau of Census, Washington, D.C. 
5. CONSERVATION MEASURE: Preheating of Process Water with Recovered Refrigeration Waste Heat

GENERAL INFORMATION

Company Name and Address

Swift and Co. P0 Box 706

Detroit Lakes, MN 56501

Telephone: (218) 847-4467

Employee Contact:

A1 Klongerbo

Plant Industrial Engineer

Plant Location:

Detroit Lakes, Minnesota

\section{INTRODUCT ION/BACKGROUND}

Statistics from the United States Department of Agriculture indicate that over 2 billion pounds of voung and old turkeys were inspected and certified "readyto-cook" in 1979. Total poultry processed, including turkeys, was almost 14 billion pounds (U.S. Department of Agriculture, 1980).

Estimates of energy usage for the poultry and egg processing industry (SIC, 2017) suggest that 5.3 trillion Btu's were consumed in 1972. Of the total energy consumed in a typical plant, frequently 12 percent is used for heating clean-up water and another 23 percent for producing process steam and hot process water (Casper, 1977).

Researchers estimate that electric energy generally accounts for approximately $35 \%$ of the total energy use in a poultry and egg processing plant (Casper, 1.977). A distribution of the typical electricity consumption in a poultry and egg processing plant is provided in the following table.

\begin{tabular}{lc}
\multicolumn{1}{c}{ Process } & Total Electrical Consumption \\
\cline { 2 - 2 } Refrigeration & 30 \\
Cooking & 15 \\
Preparation & 13 \\
Grinding, Blending, Canning & 12 \\
Egg Processing & 10 \\
Lights & 8 \\
Wateq Pumps, Steam System, Misc. & 6 \\
HVAC Equipment & 2 \\
Primary Waste Treatment & 2 \\
Compressed Air System & Total
\end{tabular}

(1) Heating, ventilation and air conditioning 
As the table shows, refrigeration is the largest single user of electricity. Energy conservation measures that focus on recovery of refrigeration waste heat are proving to be economical and effective. At Swift and Company's Detroit Lakes plant, over 35 million pounds of turkey (whole carcass) were processed in 1981. In 1980, Swift and Company installed a refrigeration waste-heat recovery system in its Detroit Lakes plant that is used to preheat plant clean-up and process water. This system has been demonstrated to be reliable and costeffective and should see widespread application throughout this and other industries in coming years.

\section{CONSERVATION MEASURE}

Plants that use conventional refrigeration systems often exhaust large quantities of heated air outside the plant. Thermal energy contained in this refrigeration exhaust is often of sufficient quality (i.e., temperature) that it could be economically recovered and used to heat other process streams within the plant. By transferring this thermal energy to processes in the plant where it can be used to perform additional work, overall plant energy savings can be realized.

Use of heat exchangers to recover waste heat from industrial processes is an important and popular method for reducing plant energy consumption, thereby conserving energy. Although actual designs may vary, the objective of heatexchanger applications is the same--to permit heat transfer from one process stream to another while preventing actual mixing of streams.

In a typical heat exchanger, fluid streams come in proximity to each other without actually coming in contact. The separating material is most frequently a metal with high thermal conductance properties. Heat exchangers are of two principal types. In the first type, latent heat from a condensing vapor is transferred through tube walls of a heat exchanger, providing sensible heat to a second fluid, which is usually a liquid. In the second type, sensible heat is transferred from one fluid to another.

A rapidly growing application of heat exchangers is to recover waste process heat from refrigeration systems. By incorporating special heat exchangers at the evaporation stage, refrigerant can be desuperheated and thermal energy 
transferred to other secondary process streams within the plant (either liquid or gaseous). In many instances, the available energy is insufficient to heat the secondary process stream to the desired final temperature(s). Heating of secondary process streams must therefore be augmented with other conventional heating methods. Under these circumstances, the heat exchanger acts to preheat secondary process streams.

\section{PLANT PROCESS MODIFICATIONS}

The Detroit Lakes plant uses a 584-ton ( 1 ton $=12,000 \mathrm{Btu} / \mathrm{hr}$ ) ammonia refrigeration system. Before plant modification, heated condenser exhaust was vented outside the plant, and no attempt was made to recover the waste heat.

Turkey plants require large quantities of hot clean-up and process water during normal plant operations. At Detroit Lakes, Swift and Company uses $140^{\circ} \mathrm{F}$ water for clean-up operations. Before modification, plant clean-up and other process water was heated solely through steam injection of city water. Swift and Company purchases excess steam from a nearby utility at the rate of approximately $13,000,000$ ibs/year. Figure 5.1 shows the various system components before retrofit.

Modifications to the existing process consisted of installing a straight shell and tube heat exchanger in front of the refrigerator condensr. Plant make-up water lines were routed through the heat exchanger in a double-pass design allowing heat transfer to occur between the superheated refrigerant and the cold plant make-up water. The installed system preheats approximately $65^{0} \mathrm{~F}$ city water to $105^{\circ} \mathrm{F}$. The temperature of the water is then boosted to $140^{\circ} \mathrm{F}$ through steam injection, just as before modification. A diagram of the modified system is protrayed in Figure 5.2 .

\section{ENERGY SAVINGS}

Energy savings that have resulted from installation of the waste heat recovery system are estimated to be 15,000 to $17,000 \mathrm{lb}$ steam/day. In theory, this quantity of steam represents the energy originally required to heat the cold make-up water to $105^{\circ} \mathrm{F}$, a job now performed by the refrigeration waste heat recovery system.

These figures translate into about 3,200,000 1b/year steam savings over a 200- 

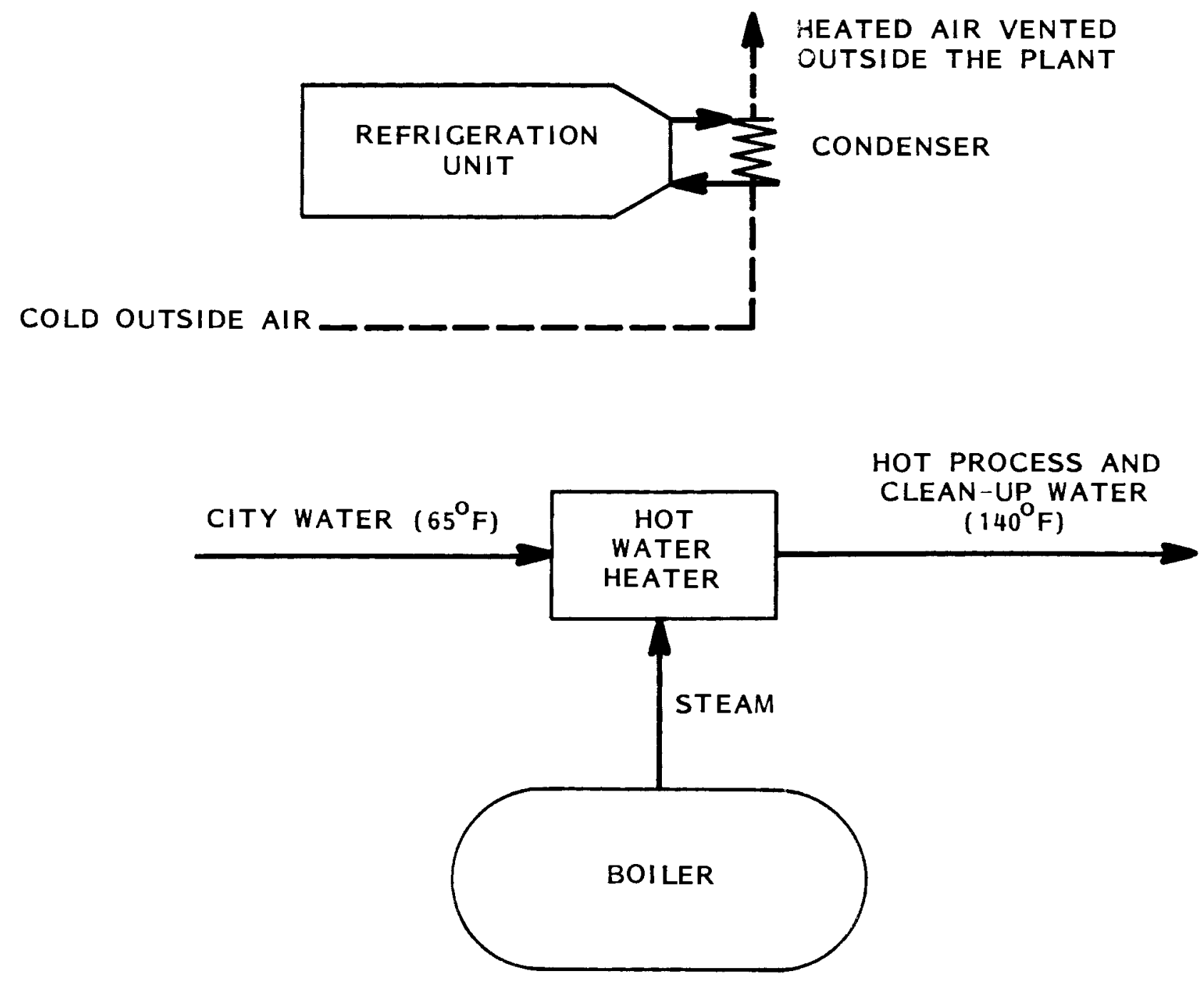

FIGURE 5.1. Process Components Before Modification to Refrigeration Waste-Heat Recovery Systems 


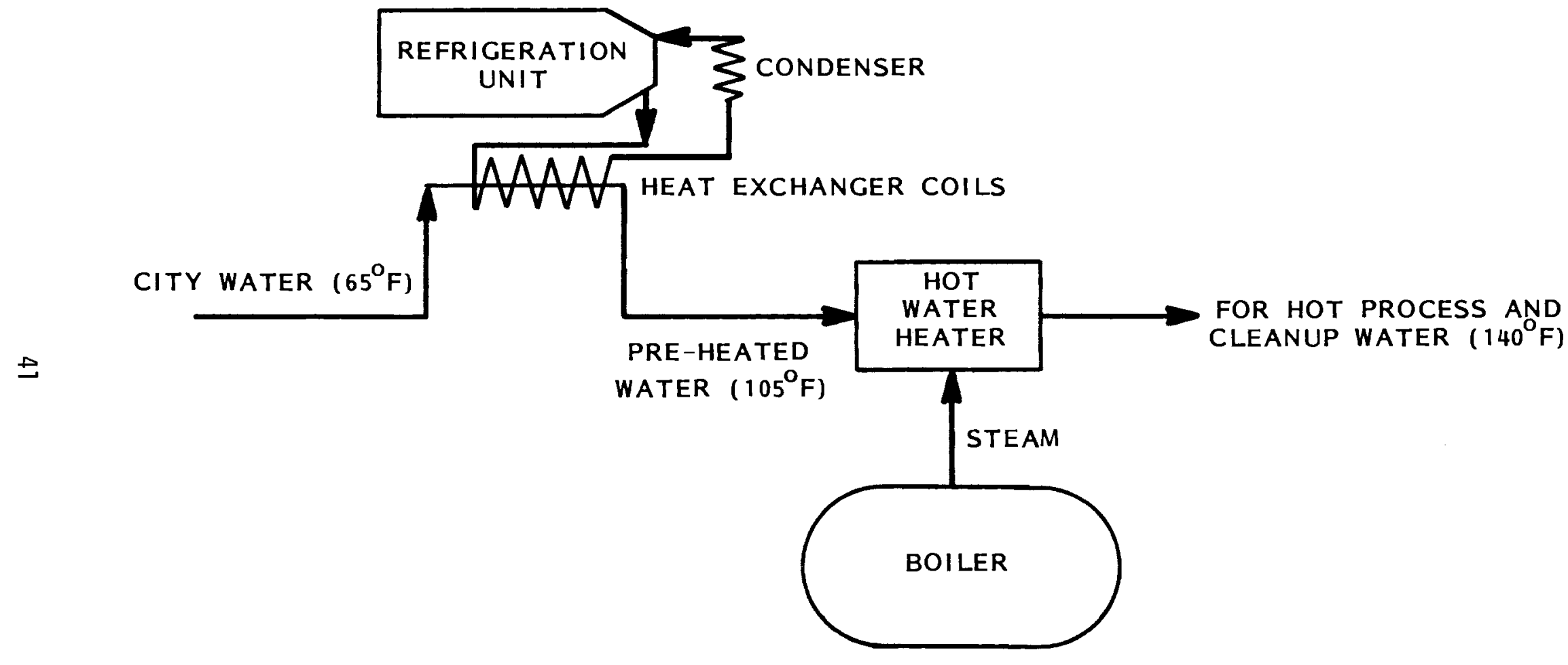

FIGURE 5.2. Preheating Process Water with Recovered Refrigeration Waste Heat 
day operating year. If a boiler efficiency of $80 \%$ and 1000 Btu/lb steam is assumed, 4 billion Btu is saved each year. This is demonstrated by:

$$
\begin{array}{c|c|c|cc}
16,000 \text { 1b steam savings } & 200 \text { day } & 1 & 1000 \text { Btu } \\
\hline \text { day } & 0.8 & \frac{1 b}{16} & 0.0 \times 10^{9} \text { Btu/year }
\end{array}
$$

Plant management estimates that the annual eneray cost savings from this energy conservation measure amount to $\$ 30,000$. Steam purchased from the nearby utility fluctuates in price throughout the year because the primary fuel source used by the utility varies from coal to natural gas; coal results in a cost of $\$ 7 / 1000$ ib steam and natural gas results in a cost of $\$ 12 / 1000$ lb steam. Thus, the $\$ 30,000$ per year savings is based upon an average fuel cost of $\$ 9.40 / 1000$ 1b steam.

\section{DECISION PROCESS}

The favorable economics of refrigeration waste-heat recovery provided the incentive to install the system. The cost of the condenser and desuperheater (heat exchanger) was $\$ 23,000$. The total capital cost, including installation, was $\$ 82,000$. Based on energy cost savings of $\$ 30,000 /$ year, a simple pre-tax payback period of $2-3 / 4$ years is projected.

The refrigeration waste-heat recovery system installed at Detroit Lakes has been reliable and requires no additional personnel. No serious maintenance problems have resulted from the retrofit, which can be installed in six weeks.

Because of the success that Swift and Company has had with refrigeration wasteheat recovery in the Detroit Lakes plant, the company is now proceeding with a similar system in its Frazee plant. Management hopes to have the system installed in the Frazee plant before start-up next spring.

\section{REFERENCES}

Casper, M. E. 1977. Energy-Saving Techniques for the Food Industry. NDC, Park Ridge, New Jersey.

United States Department of Agriculture. 1980. Agriculture Statistics 1980. U.S. Government Printing Office, Washington, D.C. 
6. CONSERVATION MEASURE: Continuous Rendering of Poultry Scraps

GENERAL INFORMATION

Company Name and Address:

North Georgia Rendering Company

Cumming, Georgia 30130

Telephone: (404) 887-6148

Employee Contact:

Mr. Thomas Bagwel1

Owner and Plant Manager

Plant Location:

Cumming, Georgia

INTRODUCTION/BACKGROUND

The rendering industry manufactures oil, grease, tallow, and meal from the by-products and waste from slaughterhouses, fish processors, and poultry processors. Production has remained stable in the last few years but the number of plants has decreased significantly. The industry is made up of independent renderers and "captive" renderers. Captive renderers are plants owned and operated by slaughtering and meat packing companies. Independent renderers are not affiliated with a meat packer or slaughterhouse and have no ensured supply of raw material (animal scraps). The rendering industry s one of the most energy-intensive processes in the meat and poultry industry because of the large amounts of water that must be removed from the feed stream. In 1979 it took 31.3 trillion Btu of energy (U.S. Department of Commerce, 1981), which is approximately $2100 \mathrm{Btu} / \mathrm{lb}$ of product, to achieve a production of 15 billion lbs. This energy cost approximately $\$ 100$ million. The energy usage is shown by intermediate users in the following table (Casper, 1977):

\section{Intermediate Uses of Energy in the Rendering Industry (in percent)}

$\begin{array}{lr}\text { Boiler } & 81 \\ \text { Direct Use } & 11 \\ \text { Electrical Inputs } & \frac{8}{100} \\ \text { Total } & 100\end{array}$

The energy used by type of fuel is shown in the following table: 
Energy Liser by Type of Fuel

in percent of total cost $\left(\$ 101 \times 10^{6}\right)$

$\begin{array}{cr}\text { Fuel 0il } & 54.9 \\ \text { Electricity } & 27.6 \\ \text { Natural Gas } & 17.5 \\ \text { Total } & 100.0\end{array}$

Of the total amount of purchased energy, electricity has remained constant at about $8 \%$ of the total amount consumed in terms of Btu equivalents, yet it is $27.6 \%$ of the total energy costs. Electrical savings, therefore, can be quite cost-effective, as the cost per Btu is much higher than for the other energy forms used. The following table details the end-use patterns of electric energy consumption in rendering plants.

Energy End-Use Activity for Electricity in Rendering Plants

(in percent)

Crushing, cooking, evaporation, screening and

71

clarification

Grinding (meal)

11

Primary waste treatment

HVAC equipment

Lighting

Miscellaneous

Total

$\frac{2}{100}$

As seen in the above table, most of the electricity is consumed in production operations, e.g., crushing, cooking, and evaporation. In an effort to reduce its electric energy consumption, the North Georgia Rendering Company modified its rendering process. The result was significant reductions in the amount of electrical energy required for pumping power to process the same amount of product. In addition to process changes, consumption of electricity can be reduced by the use of more efficient motors.

North Georgia Rendering Company is a privately owned plant that uses poultry scraps to produce cracklings (solid residues) and grease. The cracklings are in turn used to make poultry feed. In 1976 North Georgia Rendering Company 
replaced its batch-cooker system with a continuous rendering process. This new system lowered energy use, reduced operations and maintenance costs, imroved product quality and reduced environmental effluents. This continuous ystem can be used to process beef, swine, marine, or poultry scraps into meat and grease.

\section{CONSERVATION MEASURE}

In a conventional rendering operation, animal cells are broken down by mechanical and thermal action. This allows the raw fat in the cells to separate from the cell tissue. Mechanical action is achieved with grinders, which reduce the size of the beef and hog scraps. In this case, a grinder is not required because only poultry scraps, which are already small enough, are rendered. Thermal action is achieved by the use of cookers, which use great amounts of energy to separate the fat from the cellular material and to evaporate water from the mixture. The dehydrated product mixture is then separated into liquid fat and cracklings.

Because of rising energy costs and the concern over environmental effluents in recent years, there has been a move toward installing continuous rendering systems to effect energy savings and control pollution. Continuous renuering has many advantages in addition to energy savings and odor control. Some of these advantages are: reduced labor requirements, improved product quality, reduced space requirements, and easier cleaning of the system. The process steps in the continuous system are similar to the batch system, except that the cooker and press are run continuously. The continuous cooker receives a steady charge of scrap feed and discharges a steady flow of dehydrated grease and cracklings. The cracklings are then passed through a continuous press before being stored. This process is achieved with considerable energy savings as compared to the batch process for rendering.

\section{PLANT PROCESS MODIFICATIONS}

The North Georgia Rendering Company plant in Cummings, Georgia, previously used a system of batch cookers (Figure 6.1). A batch cooker is a cylindrical, agitated, horizontal vessel heated by a steam jacket. Poultry scraps are added to the cooker and heated until the moisture content is evaporated over a 


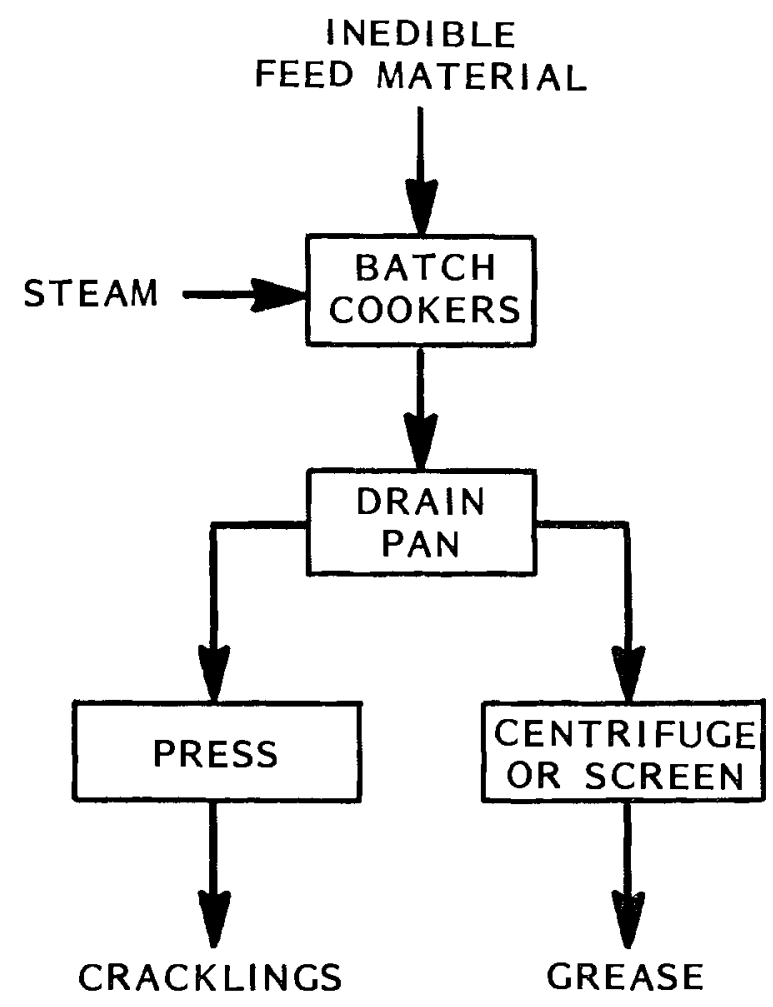

FIGURE 6.1. Batch Rendering System 
INEDIBLE

FEED MATERIAL

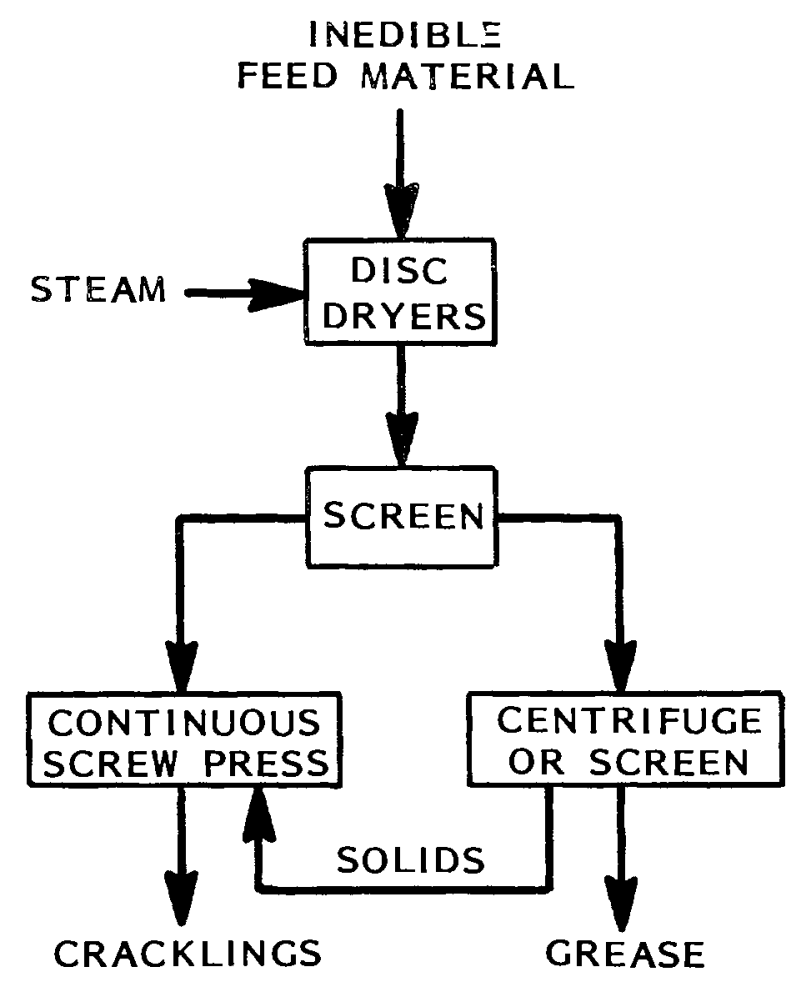

FIGURE 6.2. Continuous Rendering System 
period of hours.

When the cooking process is completed, the entire mixture is reduced to slurry form. The slurry is then discharged into a drain pan and pressed to remove the residual fat. The cracklings are separated from the grease and further processed into solid meal. The grease is centrifuged or screened to remove impurities and then stored in heated tanks to await final shipment. Batch cookers require an estimated 1000 Btu of energy in the form of steam per pound of raw material rendered. In addition, batch coolers require $700 \mathrm{hp}$ of electrical power for agitation and pumping.

The batch cookers at North Georgia Rendering were replaced in 1976 by two continuous disc dryers. Figure 6.2 illustrates the process with the continuous disc dryer. Disc dryers consist of a stationary horizontal vessel with a tubular rotor on which double-walled discs of hollow doughnut configuration are vertically mounted. The hollow discs, rotor shaft, and inner vessel walls provide the heat transfer surface. Poultry scraps are transported through the vessel by means of adjustable vanes affixed to the outer rims of the discs. The action of the vanes allows the material to be thoroughly heated, mixed and converted into cracklings and grease. The continuous disc dryer is applicable to most rendering plants and may be used in numerous other cooking processes throughout industry.

Installation of the two disc dryers resulted in reductions in operation and maintenance labor and in horsepower requirements. In addition, space requirements were reduced significantly, product quality was improved, and odors were better controlled.

\section{ENERGY SAVINGS}

The two disc dryers have small pumps that reduce the horsepower requirements from $700 \mathrm{hp}$ for the batch cookers to $200 \mathrm{hp}$. This is an electricity savings of about $1,132,000 \mathrm{kWh}$ per year. Based on current electric rates of $\$ 0.04 / \mathrm{kWh}$, the use of continuous rendering saves North Georgia Rendering Company about $\$ 45,280 /$ year in electricity costs. 
The total capital cost for each installed disc dryer was $\$ 275,000$ in 1976 . The cost in 1981 would be about $\$ 400,000$ each, or a total capital cost of approximately $\$ 800,000$ for both dryers.

\section{DECISION PROCESS}

The existing batch system at North Georgia Rendering Company was old and in need of replacement. A continuous cooking system was selected for its ability to reduce energy costs by about $\$ 45,000$ per year and for several other reasons. For example, the continuous system requires less space, provides better control of odors, and results in a labor savings of one man per shift, which is equivalant to about $\$ 45,000$ per year. The amount of maintenance needed for this new system was also reduced considerably. The total savings with all quantifiable benefits considered was about $\$ 90,000 /$ year. The product was also improved in terms of end-point temperature and moisture content. These product improvements were not quantified, but are recognized as an advantage of continuous rendering.

No significant problems have been encountered in the operation of the disc dryer system, and the installation was achieved quite easily. Within three days after installation, the plant was rendering at $100 \%$ production. The new system increased capacity, but because the supply of poultry scraps remained constant, the plant's production level has not changed.

The available data for estimating the payback period were examined and the payback was conservatively estimated to be five years with all benefits considered. North Georgia Rendering Company has also recently installed a continuous system at its plant in Alabama. In addition, the company has a boiler economizer and condensate return system in place and is considering using waste-heat recovery devices at all of its plants.

\section{REFERENCES}

Casper, M. E., ed. 1977. Energy-Saving Techniques for the Food Industry. Noyes Data Corporation, Park Ridge, New Jersey.

U.S. Department of Commerce. 1981. "Fuels and Electric Energy Consumed." 1979 Annual Survey of Manufacturers. M79(AS) -4.1 , Bureau of Census, Washington, D.C. 
7. CONSERVATION MEASURE: Electrical Stimulation of Beef

GENERAL INFORMATION

Company Name and Address:

Sam Kane Beef Processors, Inc.

PO Box 9254

Corpus Christi, TX 78408

Phone Number: 512-241-2311

Employee Contact:

Jerry Kane

Plant Manager

Russ Beck

Plant Location:

Corpus Christi, Texas

\section{INTRODUCTION/BACKGROUND}

In $1979,3.57$ billion pounds (live weight) of cattle were slaughtered in the United States under federal inspection, and 2.14 billion pounds of beef (dressed weight) were produced (U.S.D.A., 1980). The production of this beef required that meat packing plants purchase 71.1 trillion Btu's of energy (U.S. Department of Commerce, 1981). The energy forms expended to produce beef are shown in he following table (Casper, 1977).

Energy Used by Meat Packing Plants

$\begin{array}{lc}\text { in percent of total cost }\left(\$ 225.0 \times 10^{6}\right) \\ \text { Electricity } & 47.1 \\ \text { Natural Gas } & 26.1 \\ \text { Fuel 0ils } & 13.4 \\ \text { Other Total } & \frac{13.4}{100.0}\end{array}$

The electricity share has remained constant over the last few years at approximately $15 \%$ of the total amount consumed in terms of Btu equivalents. The above figures suggest that saving electricity can be quite cost effective, because the cost per Btu of elecricity is much higher than for the other energy forms used.

The following table details the end-use patterns of electricity consumption in meat packing plants. 


\section{Energy End-Use Activity for Electricity in Meat Packing Plants

$$
\text { (in percent) }
$$

$\begin{array}{lr}\text { Refrigeration } & 37 \\ \text { Process Preparation, Cooking, Packing } & 18 \\ \text { Rendering } & 12 \\ \text { Lighting } & 14 \\ \text { Compressed Air } & 5 \\ \text { HVAC Equipment } & 4 \\ \text { Steam and Water Use } & 4 \\ \text { Waste Treatment } & 4 \\ \text { Other } & \text { Total } \\ & \end{array}$

Refrigeration energy can be conserved through:

1. a reduction in refrigeration demand (load)

2. increased refrigeration cycle efficiency

3. waste-heat recovery from refrigerant cycle.

The specific area of interest in this case is the reduction of refrige:ation demand. This can be accomplished most efficiently by reducing the amount of product that needs to be cooled down or stored, and by minimizing the time the product spends in refrigerated storage. The other methods of reducing demand (insulation, weather stripping, and air curtains), are also important but not as direct. The conservation measure considered in this case, electrical stimulation of beef, reduces the load or demand for refrigeration.

Sam Kane Beef Processors is a leading meat packer in southwestern Texes and is one of the nation's largest slaughterers and processors of yearling cattle. Cattle slaughtering is performed at a rate of 600 head/day to produce sides of beef, boxed beef, hamburger, and other products. The cattle generally dress out in a weight range of 400 to 600 pounds. Sam Kane Beef Processors was the first large meat packing company to use electrical stimulation of beef. This innovation was the latest added by the company to its modern plant at Corpus Christi, Texas. Such advanced techniques as on-rail slaughtering, portion control equipment, computer controlled selection of cattle to be slaughtered, plastic wrapping of cuts via a vacuum-shrink operation, and the introduction of 
boxed beef sales have made Sam : ane Beef Processors one of the more innovative processors in the United States. The use of electrical stimulation was incorporated after several years of research at Texas A\&M, under the financial and technical support of the United States Department of Energy, and in association with Sam Kane Beef Processors.

CONSERVATION MEASURE

The first researcher to use electrical stimulation was Benjamin Franklin, who in 1749 found that, "...killing turkeys electrically has the pleasant side effect that it made them uncommonly tender." (Schlender, 1979). This was the first practical application that had been found for electricity. Electrical stimulation was not widely researched again until the mid-1950s.

Researchers in New Zealand, England, and the United States have been researching the use of electrical stimulation to tenderize meat. Electrical stimulation also provides a more palatable product (Save11, 1978b). Chemical changes after shock treatment cause the muscle tissue to relax, which increases tenderness and makes the meat more acidic (Save11, 1978a). The increase in acidity activates natural enzymes that enhance flavor and tenderness. Sam Kane Beef Processors has also noted that the meat has a brighter, more attractive marbling and color, longer case-life, and shorter cooking time.

Electrical stimulation results in energy savings as well as other benefits to the processor. Energy savings resulted because the aging time was greatly reduced. This reduced refrigeration time by one-half to about one day per carcass. Refrigeration expense in meat processing plants is quite high because the beef must be aged before the U.S. Department of Agriculture grades it. After the grading process, the meat is shipped to the customer. Refrigeration storage time for beef is determined by the cut of meat. Electrical stimulation reduces the aging time for steaks by about two-thirds. The aging time before grading was also reduced, because electrical stimulation prevents the formation of "heat-ring", which is caused by rapid chilling and lack of time spent in chilled storage (Savell, 1978). Beef that develops "heat-ring" is returned to chilled storage and must be regraded. 


\section{PLANT PROCESS MODIFICATIONS}

Before modification of the production line to incorporate the electrical stimulation equipment, the following operational sequence was used in the processing of beef cattle. The animals were killed, bled, and beheaded in the kill room, then sent to the production line where the carcasses were skinned, eviscerated, split, trimmed, and shrouded. The carcasses were then put into coolers to age before the grading process. After grading, the carcasses were sold or cut-up for further packaging. The steak-bound cuts were held in an aging cooler at $33^{\circ} \mathrm{F}$ for 21 days before they were cut and wrapped.

In 1978, Lefiell Company designed and then installed the electrical stimulation equipment on the production line between the skinning and gutting operations. The equipment consists of two metal bars that automatically swing into position and contact two carcasses, side by side. Once contact is established, nine pulses of electricity (600 volts dc) are passed through the carcasses. The carcasses are then moved down the line one station and subjected to nine more pulses of electricity. In this way each carcass receives a total of 18 pulses of 600 volts $d c$. The total floor space required is $4 \times 10$ feet; no operators are needed.

After being gutted, trimmed, and shrouded, the carcasses are cooled. Electrical stimulation has decreased cooling by half the previous time, or one day. Graded, steak-bound cuts are cooled for seven days instead of the previous 21.

\section{ENERGY SAVINGS}

The exact amount of electricity saved per unit of production after plant modification is not known because the physical plant was expanded as the electrical stimulation equipment was installed. Aging time varies with each cut of meat; steaks require the longest time. The use of electrical stimulation on the carcasses results in one day less refrigeration before they are graded. The reduced refrigeration time results in major energy savings and allows more carcasses to be cooled. Although no plant readings of this particular refrigeration process are available, the staff at Sam Kane Beef processors has estimated the energy savings amounts to 300 tons of 
refrigeration. This energy savings is equivalent to $300 \mathrm{hp}$ for 24 hours or $7200 \mathrm{hp}-\mathrm{hr}$ per day. The electrical stimulation equipment operates at 208 volts and 18 amps for 16 hours per day for an energy use of about $60 \mathrm{kWh}$. The energy saved is $7200 \mathrm{hp}-\mathrm{hr} \times 0.746 \mathrm{kWh} / \mathrm{hp}-\mathrm{hr}-60 \mathrm{kWh}=5300 \mathrm{kWh} /$ day. Assuming 350 days/year of operation, the annual savings are 1,860,000 kWh or 6.3 billion Btu/yr. This figure is conservative because it does not include the energy savings from the reduction in aging time for the steaks.

The electrical stimulation system was purchased in 1979 at a cost of $\$ 80,000$. Sam Kane also invested capital in the research at Texas A\&M. Total costs, including research and installation costs, ranged from $\$ 175,000$ to $\$ 200,000$. Al1 cooling systems at the plant are electrically operated. A conservative cost savings from the electrical stimulation installation based upon the previously estimated savings of $1,860,000 \mathrm{kWh}$ is about $\$ 97,000 /$ year. The Sam Kane facility uses $900,000 \mathrm{kWh}$ of electricity per month at a price of $\$ 0.052 / \mathrm{kWh}$ for a total cost of $\$ 45,000 /$ month or $\$ 540,000 /$ year.

\section{DECISION PROCESS}

Increased tenderness, longer case or shelf-life, improved appearance, enhanced flavor, diminished shrinkage in the cooling process, and less cooling time are quality and process improvements that prompted the installation of the electrical stimulation equipment. Reduced inventory and associated space savings were also realized by Sam Kane Beef Processors, Inc. Consumer demands are met more quickly because of the reduction in time from slaughtering to shipping the final product. No new labor was needed because the system operates in an automatic mode. Very little additional maintenance is required because of the self-cleaning nature of the equipment.

The equipment was easily installed and required very little space or training of personnel. Because of the high voltages of electricity used in the process, extreme caution is used in operating the equipment. Safety was enhanced by designing the equipment properly and by instituting strict operating procedures. No problems have occurred using the equipment and no further improvements in electrical stimulation are expected in the near future.

Quality improvements were the major justification for installing the electrical 
stimulation process. Energy savings, though important, simply added to the attractiveness of this process improvement. Using only the conservative cost savings estimate of $\$ 97,000 / y r$ and the total cost of about $\$ 200,000$, which includes research muney invested by Sam Kane Beef Processors, the payback period is about 2 years. Thus, the energy savings alone make the installation of electrical stimulation equipment attractive.

\section{REFERENCES}

Casper, M. E., ed. 1977. Energy-Saving Techniques for the Food Industry. Noyes Data Corporation, Park Ridge, New Jersey.

Save11, J. W., Smith, G. C., and Carpenter, Z. L. 1978. "Beef Quality and Palatability as Affected by Electrical Stimulation and Cooler Aging." J. Food Sci. 43:1666.

Save11, J. W., Dutson, T. R., Smith, G. C., and Carpenter, Z. L. 1978a. "Structural Changes in Electrically Stimulated Beef Muscle." J. Food Sci. $43: 1606$.

Save11, J. W., Smith, G. C., and Carpenter, Z. L. 1978b. "Effect of Electrical Stim!lation on Quality and Palatability of Light-Weight Beef Carcasses." J.Anim. Sci. 46:1221.

Schlender, B. R., "Shock Treatment is Said to Enhance Tenderness of Beef." Wall Street Journal, June 26, 1979, p. 28.

U.S. Department of Agriculture. 1980. "Fuels and Electric Energy Consumed." 1979 Annual Survey of Manufacturers. M79(AS)-4.1, Bureau of Census, Washington, D.C. 
8. CONSERVATION MEASURE: $\begin{gathered}\text { Preheating and Storing Process Water with Recovered } \\ \text { Refrigeration Waste Heat }\end{gathered}$

GENERAL INFORMATION

Company Name and Address: Armour Food Company

Greyhound Towers

111 West Clarendon

Mail Stop 901

Phoenix, AZ 85077

Telephone: (602) 248-5246

Employee Contact: Brian Woods

Corporate Energy Engineer

Plant Location: Mason City, Iowa

\section{INTRODUCTION/BACKGROUND}

In 1972, over 5.1 billion pounds of sausage and prepared meats (SIC 2013) were produced in the United States. Major products within this category include: processed and cured pork ( 1.5 billion pounds produced in 1972 or $30 \%$ of production), sausage and similar products not canned (2.6 billion pounds or $50 \%$ of production), and canned meats $(0.8$ billion pounds or $1.5 \%$ of production). 0ther products include various types of sausage casings (5\% of production). Estimates in 1977 projected steadily increased production through 1980 to levels approaching 6.1 billion pounds (Casper, 1977).

While energy consumption patterns vary, energy input requirements can be as high as 10,000 to 12,000 Btu's per pound of product. Major energy consumption within a plant can be attributed to cooking, cooling, and losses due to boiler inefficiencies.

In the sausage and prepared meat industry, approximately 32 percent of overall plant energy consumption goes directly into producing process steam and hot water. Hot water is used both in processing and plant clean-up operations. Electrical energy usage often comprises 17 percent of total plant energy consumption. The single largest consumer of electricity is the refrigeration system. Typically, 30\% of electrical demand is generated by refrigeration in the sausage and prepared meats industry (Casper, 1977).

Armour Food Company recently installed a refrigeration waste-heat recovery 
system in its Mason City, Iowa, plant. The Mason City plant produces 1 million pounds of processed pork and beef products each week. The heat recovery system has resulted in vast energy savings and subsequent cost savings to the owners.

\section{CONSERVATION MEASURE}

Conventional refrigerational systems enable the transfer of thermal energy within a substance to a circulating refrigerant, vis-a-vis evaporator coils. Thermal energy acquired by the refrigerant is then transferred outside of the refrigeration cycle to another medium by condenser coils, and chilled refrigerant is recycled through the system. In an overwhelming majority of cases, air is the medium that is forced over the condenser coils, cooling the refrigerant and acquiring sensible heat in the process. This exhaust air is then generally vented outside of the plant.

Often, the temperature of air exhausted from these refrigeration systems is sufficiently high that thermal energy in the air can be economically recovered and used elsewhere in the plant. One of the most common applications for this recovered energy is to use it to heat or preheat other process streams within the plant by using heat exchangers. While designs may vary, the objective of heat exchangers is the same -- to permit heat transfer from one process stream to another, while preventing actual mixing of streams. Evaporator and condenser coils used in refrigeration cycles are two examples of heat exchangers.

In a typical heat exchanger, fluid streams come in proximity to each other without actually contacting each other. The material used to separate the streams is most often a metal with high thermal conductance properties. The individual process streams can be composed of any combination of liquids, gases, or solids. Heat exchangers designed for liquids and gases are the most common.

Specially designed heat exchangers can be installed immediately in front of the evaporator coils in a refrigeration system to recover waste heat. Thermal energy can be recovered (corresponding to the high-temperature desuperheating range of the circulating refrigerant) and transferred directly through the heat exchanger to other process streams within the plant that require heating, or that could benefit from preheating. 

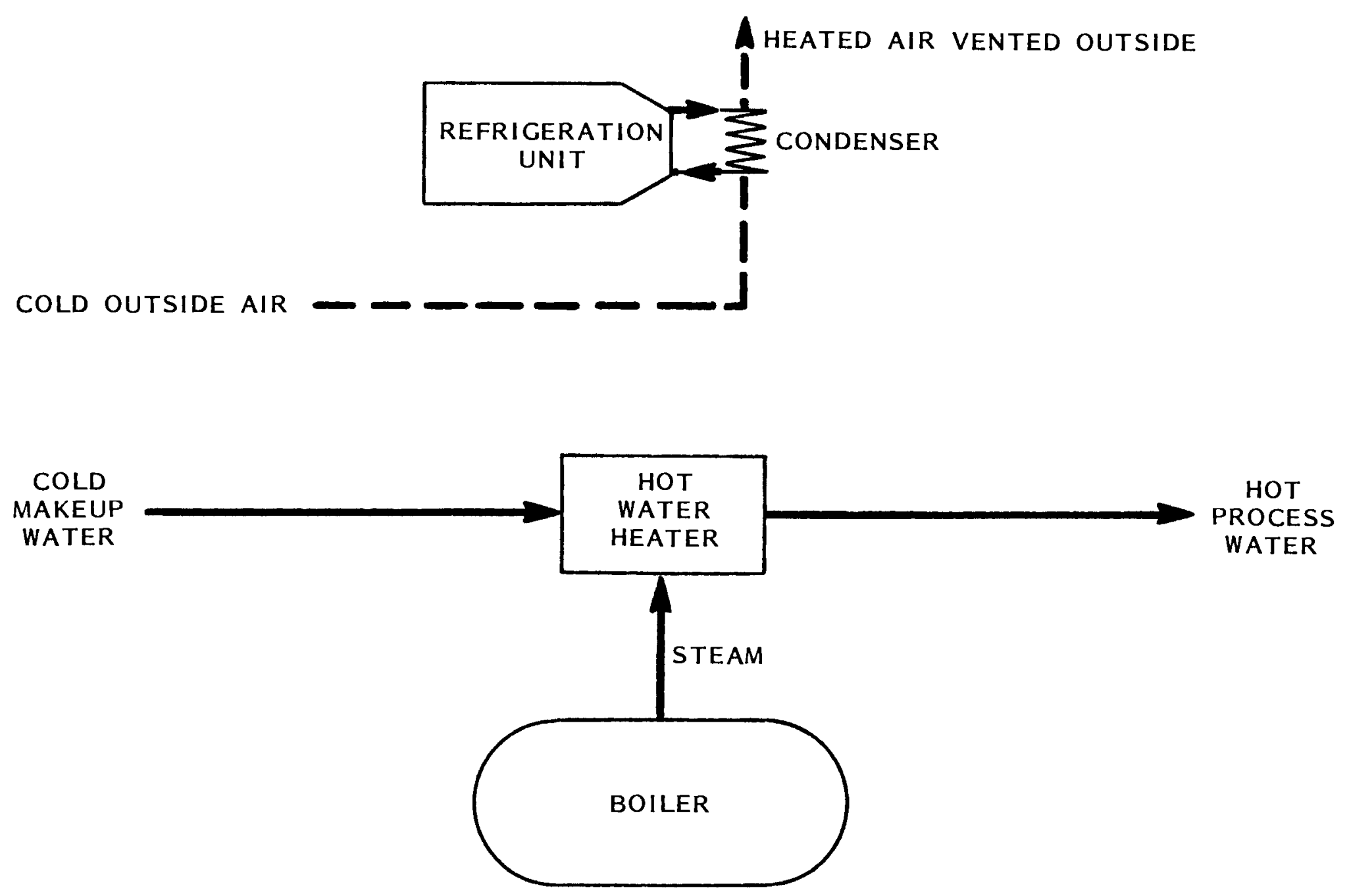

FIGURE 8.1. Plant Process Components Prior to Modification for Waste Heat Recovery 
Meat processing and packing plants typically use vast quantities of electricity for refrigeration. Conventional refrigeration systems transfer heat from a product to a refrigerant. In turn, the refrigerant transverses a series of coils in an evaporator, where heat is transferred to air passing over the coils. The heated air that has been forced over the coils by fans is normally expelled outtside of the plant. Discharging heated air in this way results in wasted energy.

To use otherwise wasted energy, Armour Food Company has installed a heat recovery system designed to preheat process make-up water with rejected heat from the refrigerator condenser. The modification has produced substantial energy savings and is applicable to nearly all industries that use large refrigerators and require heated process water in the plant or have other process streams that could benefit from preheating.

The 1,350-ton (where 1 ton $=12,000 \mathrm{Btu} / \mathrm{hr}$ ) compound refrigeration system at Armour is made up of a low and a high stage. The low stage is used for cooling from approximately $20^{\circ} \mathrm{F}$ to $10^{\circ} \mathrm{F}$; the high stage is used for cooling from ambient temperature to $20^{\circ} \mathrm{F}$. At Armour, only the high stage compressors include heat recovery equipment and contribute directly to the recoverable superheat for the waste-heat recovery system. (Waste heat is at a higher temperature.)

The high-stage system at the Mason City plant consists of a combination of two rotary screw compressors and six reciprocating compressors. The rotary screw compressors provide baseload refrigeration while the reciprocating compressors engage, as necessary, to meet peak load demands. Because of its compressor characteristics, the screw compressor produces a hot discharge with a heating value of about $652 \mathrm{Btu} / \mathrm{lb}$ at $110^{\circ} \mathrm{F}$. Hot gas discharge from the reciprocating compressors carries about $735 \mathrm{Btu} / \mathrm{lb}$ at $245^{\circ} \mathrm{F}$ (Murphy, et al., 1980).

Before modification, the thermal energy from desuperheating and condensing the refrigerant was vented to the exterior of the plant. Hot water required in the plant was generated only through steam heating of city water from a boiler with an efficiency estimated at $78 \%$. A diagram of the original process is shown in Figure 8.1 . 
The heat recovery system instaiie at the Mason City Armour plant in 1979 consists of a shell and tube heat exchanger applied to the compressor hot gas discharge line. Water is continuously recirculated from a 23,000-gallon tempered-water storage tank to the heat exchanger by a circulating pump at the rate of 100 gallons per minute, providing 0.5 to $1.0 \mathrm{million} \mathrm{Btu} / \mathrm{hr}$ heat recovery. All make-up water to the plant's hot water system is supplied from this tempered-water storage tank, which is maintained at a constant filled level.

Water is pumped from the storage tank to the plant heaters by a three-pump set. As water is pumped to the plant heaters, cold make-up water $\left(75^{\circ} \mathrm{F}\right)$ replaces the used water. Average use of hot water throughout the plant is estimated at 147,000 gallons per day.

The installed heat recovery system is designed to recover waste heat at higher temperatures that correspond to the desuperheating range of the refrigerant. Full condensing heat recovery would have recovered more total heat, but it was questionable whether the lower-temperature heat recovery would be sufficiently cost effective to justify a larger installation. A diagram of the modified process is given in Figure 8.2 .

\section{ENERGY SAVINGS}

Armour management has expended considerable effort to determine the actual energy savings resulting from retrofit. Based on metered temperature and flowrate data, it was conservatively estimated that 16 million Btu of reusable waste heat is extracted and used each day from the waste-heat recovery system. At 78\% boiler efficiency, this energy savings translates to 20.5 million Btu/day in fue 1 savings.

Based on prevailing energy prices in mid-1979, the refrigeration waste heat recovery system was estimated to save $\$ 29,300 / \mathrm{yr}$. This figure assumes a boiler efficiency of $78 \%$, No. 2 fuel oil priced at $\$ 0.80 / \mathrm{gal}$, and a 250 day/year operating schedule. The heating value of 1 gallon of No. 2 fuel oil is taken as 140,000 Btu. Calculatons were performed as follows:

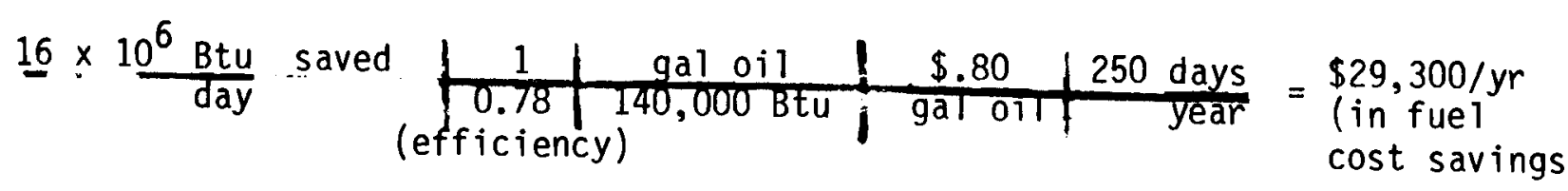




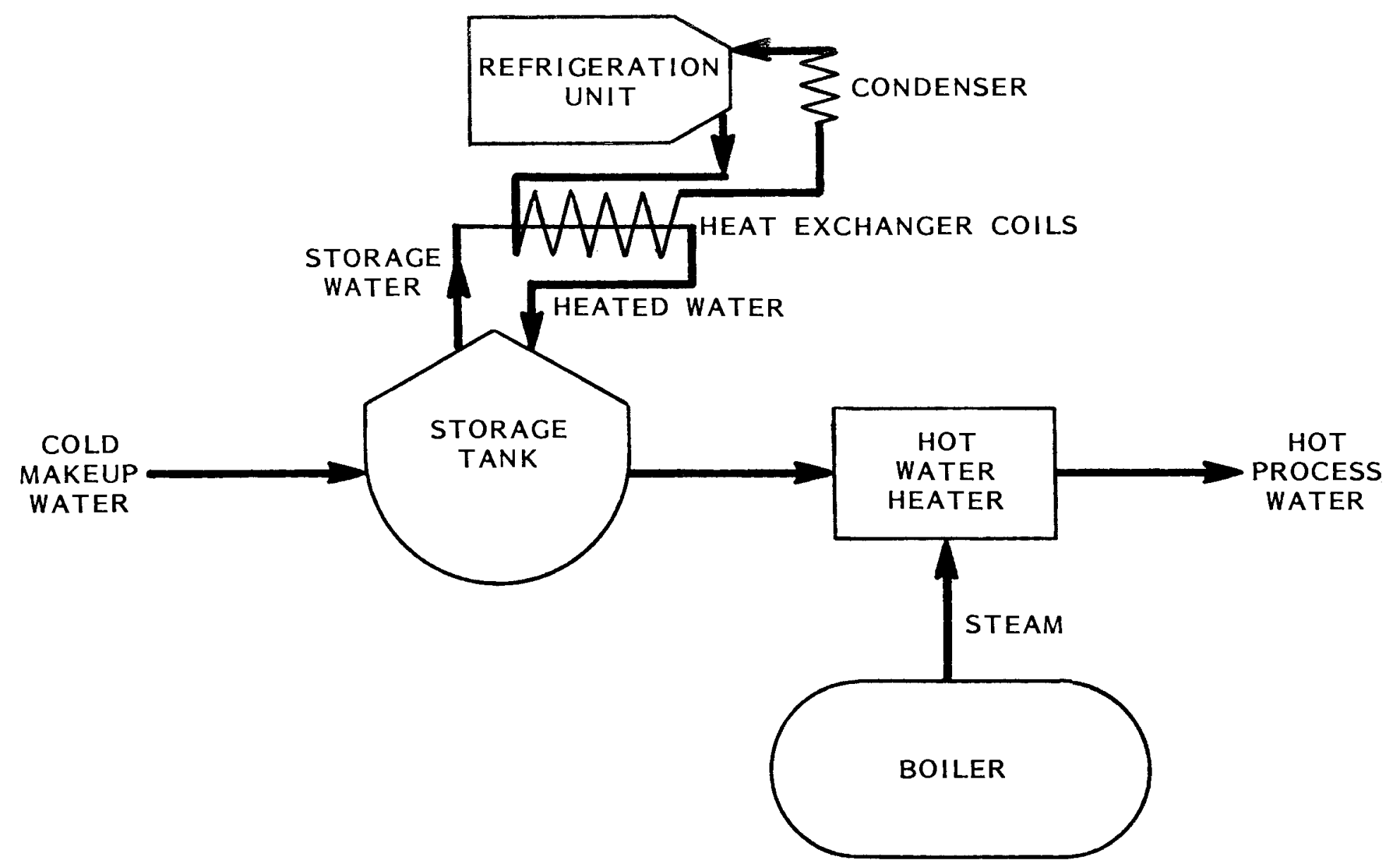

FIGURE 8.2. Preheating and Storage of Process Water with Recovered Waste Heat 


\section{DECISION PROCESS}

The Mason City plant was opened in 1978 and was originally designed to incorporate refrigeration waste-heat recovery. However, a shortage of capital meant that the new plant had to be stripped of all nonessential equipment and the refrigeration heat-recovery system was not built. A short while later, capital became available and the system was examined for retrofit potential. Initial estimates suggested that the project could produce annual energy savings on the order of one-third the total installation cost.

On this basis, the heat recovery project was undertaken. Actual energy savings have been estimated at $\$ 29,300 /$ year, and the 1979 capital cost (including installation) was $\$ 78,800$. These figures result in a 32 -month, simple, pre-tax payback period based on energy cost savings alone. Armour believes this estimate of payback to be conservative.

Additional economic incentive was provided in two other areas. First, it was recognized that the price of oil would probably escalate over the 2- to 3-year payback period anticipated for the project. Second, the Energy Tax Act of 1978 allows a 10 percent investment tax credit for projects of this kind, because they are energy conservation measures. Although no actual figures are yet available, the combination of these factors was expected to significantly reduce the payback period of the retrofit, thus providing additional economic stimulus.

No significant problems with installation or operation have been experienced since the system was purchased and brought on-line nearly 2-1/2 years ago. No additional personnel are required to operate the system, and maintenance costs are minor when compared to energy savings.

\section{REFERENCES}

Casper, M. E. 1977. Energy Saving Techniques for the Food Industry. Noyes Data Corporation, Park Ridge, New Jersey.

Murphy, W. T., Woods, B. E., and Gerdes, J. E. 1980. "Waste Heat Recovery from Refrigeration in a Meat Processing Facility". Technical paper: internal publication, Armour Food Company, Phoenix, Arizona. 
9. CONSERVATION MEASURE: Microcomputer Control System

GENERAL INFORMATION

Company Name and Address: Land O'Lakes, Inc.

702 13th Street

Albert Lea, MN 56007

Telephone: (507) 373-0641

Employee Contact: Tom Hansen

Senior Plant Engineer

Plant Location: Albert Lea, Minnesota

INTRODUCTION/BACKGROUND

Statistics from the United States Department of Agriculture indicate that over 2 billion pounds of young and old turkeys were certified "ready-to-cook" in 1979. Total poultry certified was almost 14 billion pounds. Of the 2 billion pounds of turkey certified and cooked in 1979, approximately $38 \%$ was further processed (excluding whole carcass preparation) (U.S.D.A., 1980).

Estimates of energy usage for the poultry and egg processing industry (SIC 2017) suggest that 5.3 trillion Btu's were consumed in 1972. Researchers estimate that electricity generally accounts for approximately 35\% of the total energy usage of a poultry and egg processing plant (Casper, 1977). A distribution of the typical electricity consumption in a poultry and egg processing plant is provided below.

\section{Process}

Process

Total Electrical Consumption

(in percent)
Refrigeration

Cooking

Preparation

Grinding, Blending, Canning

Egg Processing

Lights

Water pumps, Steam System, Misc.

HVAC Equipment

Primary Waste Treatment

Compressed Air System

Total
30

15

13

12

10

8

6

2

2

2 
Various technological improvements can be implemented to conserve energy in poultry processing plants. Use of electricity is one possible area of energy conservation. Refrigeration is one process where it may be technologically practicable in some instances to save large quantities of electrical energy. However, because other electricity-consuming processes provide minor contributions to the composite level of total electricity usage, only small reductions in total electricity consumption can be expected when attempting to improve the technology of each end-use process, relative to the costs involved. A more practical approach to conserving electricity in this case would be to initiate an energy management system that would more closely match use with actual demand patterns. In this fashion, unnecessary usage could be avoided and energy could be conserved during the day.

In 1979, Land O'Lakes installed a computerized energy-management system in its Albert Lea, Minnesota, turkey processing plant to conserve energy and reduce energy costs.

The Albert Lea plant produced 37 million pounds of processed turkey products in 1981. The microcomputer energy-management system has decreased energy consumption. It has more evenly distributed the energy load during the day, resulting in reduced peak load energy costs, as well as cost savings from reduced energy usage.

The microcomputer control system adopted by Land O'Lakes is widely applicable in the meat industry, and others as we11. Any process that could benefit from continuous or semi-continuous monitoring and automated feedback control could use the microcomputer control system. Energy savings could be realized from a wide variety of applications.

\section{CONSERVATION MEASURE}

Typically, electrical bills for commercial or industrial buildings are determined by four individual charges: a consumption charge, demand charge, fuelcost adjustment charge, and a power factor charge. Consumption charges are based on the total electrical usage over a designated billing period. Demand charges cover high, short-term electrical requirements over the billing period. Fuel-cost adjustment charges protect the utility from fluctuations in the cost of fuel to generate the electrical energy. And power factor charges penalize the user for low building power factors which require larger electrical services than indicated by the demand requirements. 
A high energy load factor (1) is the result of a good energy management system. The two key objectives of energy management are to:

1. reduce energy consumption by limiting energy use to when and where it is needed, thus conserving electricity

2. reduce the peak demand by programming individual load operations so that they will not function simultaneously.

Several methods of energy management may by used in a building to reduce energy costs. These methods range from the obvious scheduling of loads to the more sophisticated methods that include demand control and load cycling.

When a utility company charges for demand requirements, the utility will use the highest demand required during short periods of time and bill for that demand over the entire billing period, usually a one-month interval. The buyer must pay for that demand for the entire month whether his usage approaches that level again or not. In addition, many utilities will use a high percentage of that demand in future months, provided that it is not exceeded, to determine the monthly demand charges for those months.

As energy demand approaches the demand limit, an energy management system can regulate or shed loads to maintain the total demand within the demand unit. Many utilities are actively encouraging their customers to consider installing demand control equipment to stretch the service they can provide with their existing generating plant capacities.

The total cash savings attainable through energy-consumption and demand management for a building depends on, and proportional to, the number of controllable loads in a system and the actual energy conserved. The larger the number of loads subject to control, the greater the possibility of energy savings.

Proper operation and savings depend on how we 11 basic information is collected in laying out the control of the system. A building graphic of the energy management system should, therefore, be developed in close cooperation with the building designer. One leading reason for failures or poor results with energy management systems in existing buildings is that system and components are misapplied.

(1) Energy load factor is defined as the ratio of energy consumed to the maximum possible energy consumption at that level of energy demand. 
To be effective comprehensive energy management systems (which include extensive load scheduling, demand control, and load cycling), should be centrally located and automated.

In addition to providing significant savings in electricity costs, an automated energy-management system can provide reliable, continuous operation night and day and on weekends with a minimal number of people. This also leads to savings. At the same time, additional functions such as building function monitoring and alarm operations may also be installed at minimal cost, further reducing personnel requirements.

One of the major obstacles to overcome in providing a centrally located, automated energy management system involves the network for transmitting the control signals from the control center to the individual loads located throughout the building. There are two methods of transmitting signals to the load locations: parallel wiring from the controller to each individual load or multiplexing a group of signals from the controller over common wires to stations conveniently located near groups of loads (McQuay-Perflex).

Parallel wiring requires the routing of two wires from the controller to each load. When you consider the potential number of loads in a system, it is obvious that this method could be expensive and time consuming to install.

Multiplexing consists of converting on/off signals of all loads into a coded signal and transmitting this signal over a single pair of wires to a remote station. This station demultiplexes the signal back into the on/off functions. By employing a number of interface stations around the building, it is possible to control all of the loads of the system with only several hundred feet of wire. The system software can provide the multiplexing signal. The demultiplexing stations are the only additional items required.

\section{PLANT PROCESS MODIFICATIONS}

In mid-1979, Land 0'Lakes installed a microcomputer system that now manages most of the important electric load elements of the Albert Lea, Minnesota, plant. The desktop console, which is the "brains" of the unit, and the interface stations which perform control and/or monitoring functions dictated by the main console, are the two major components of the microcomputer system.

The interface stations actually interface between sensing devices, control equipment, and the main console. A diagram of the system's component

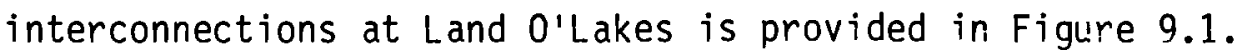




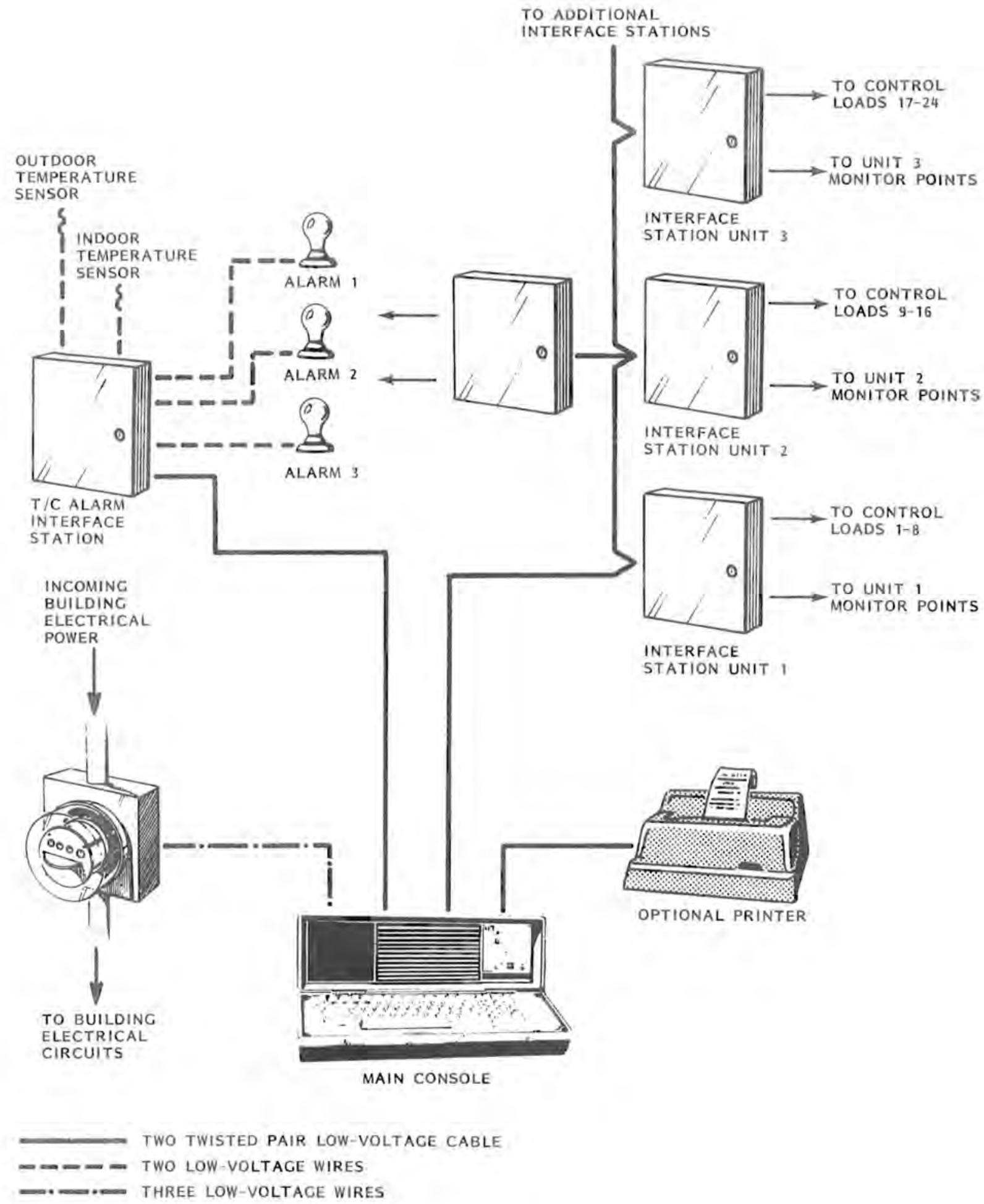

FIGURE 9.1. Component Interconnections of a Typical Microcomputer Energy Management System (after McQuay-Perflex, Inc.) 
The microcomputer helped identify actual demand-versus-time relationships for refrigeration, defrosting, ventilation fans, air conditioning, and lighting needs. After demand/time relatiorihips for electric consumers in the plant were identified, management developed a schedule that moved the load of nonessential equipment to periods of low demand. Equipment based on real time monitoring via remote sensing devices is now automatically controlled.

Compressor operation and refrigeration defrosting are now performed automatically based on monitoring of actual needs. Other equipment such as lights are controlled automatically on a time basis that is predetermined by the new-energy saving demand-versus-time schedule.

\section{ENERGY SAVINGS}

Electricity savings for the Albert Lea plant attributed to the energymanagement system are estimated to be 100,000 to $150,000 \mathrm{kWh} / \mathrm{month}$, which corresponds to a processing rate of 37 million pounds of turkey/year. An exact breakdown of electricity savings for equipment is not available.

Based on 1979 electricity prices of $3.2 \$ / \mathrm{kWh}$ and on an average monthly energy savings of $125,000 \mathrm{kWh}$, the microcomputer system saves an estimated $\$ 48,000 /$ year. At current electricity prices $(5.3 \$ / \mathrm{kWh})$, energy cost savings range from $\$ 64,000$ to $\$ 95,000$ per year.

\section{DECISION PROCESS}

The decision to install the microcomputer energy management system was based solely on the economics of expected energy savings. The system was installed in 1979 at a cost of $\$ 42,500$. Assuming that the cost savings based on energy savings alone were $\$ 48,000 /$ year in 1979 , a simple pre-tax payback period is estimated to be less than 1 year.

The microcomputer energy-management system was easily installed at Land 0'Lakes, and control activities can be expanded as needed. There has been no change in the number of operators required at the plant, and very few maintenance problems have developed.

In addition to electricity cost savings at Land 0'Lakes, the energy management system was used to monitor security detectors in the plant. As a result, fewer security personnel were required, and cost savings were realized here also. No further modifications are planned at this time. 


\section{REFERENCES}

Casper, M. E. 1977. Energy-Saving Techniques for the Food Industry. Noyes Data Corporation, Park Ridge, New Jersey.

McQuay-Perflex, Inc. Energy Management... An Overview by McQuay. Product Brochure. Minneapolis, Minnesota.

United States Department of Agriculture. 1980. Agriculture Statistics 1980. U.S. Government Printing Office, Washington, D.C. 
10. CONSERVATION MEASURE: Housekeeping Improvements

GENERAL INFORMATION

Company Name and Address: Oscar Mayer and Co. P0 Box 7188

Madison, WI 53707

Employee Contact: Vern Karman

Energy and Utilities Manager

Plant Locations: Perry, Iowa and Beardstown, Illinois

\section{INTRODUCTION/BACKGROUND}

In 1979, 2.07 billion pounds (live weight) of hogs were slaughtered under federal inspection in the United States. This resulted in the production of 1.47 billion pounds of pork meat (U.S.D.A., 1980). The meat packing industry used 71.1 trillion Btu of energy in 1979 (U.S. Department of Commerce, 1981). Much of this energy was boiler fuel, and the balance was composed of purchased electricity and steam or fuel for direct use. The following table shows the distribution of energy usage in meat packing plants (Casper, 1977).

\section{Energy Use Distribution in Meat Packing Plants}

(in percent)

$\begin{array}{lr}\text { Boiler Fuel } & 76 \\ \text { Purchased Electricity } & 14 \\ \text { Fuel for Direct Use } & 8 \\ \text { Purchased Steam } & \frac{2}{100}\end{array}$

Each of these categories can be affected by housekeeping and small capital investment projects.

To further examine the categories, their end-uses were evaluated. Boilers, for example, the major energy user in the meat packing industry, are used to generate steam for several operations within the plant. A summary of boiler steam usage is provided in the following table. 
Energy End-Use of Boiler Steam in Meat Packing Plants

(in percent)

\begin{tabular}{lr} 
Rendering Operations & 34 \\
Hot-Water Cleanup & 20 \\
Heat Boiler Feed Water & 16 \\
Space Heat and Process Steam & 16 \\
Hot-Water Production & $\underline{14}$ \\
\hline & 100
\end{tabular}

Although the use of electricity accounts for only about $14 \%$ of the Btu's consumed in a meat packing plant, the amount of money spent on electricity in an average plant is approximately $44 \%$ of the total energy bil1. Thus, electricity is by far the most expensive energy source on a dollar per Btu basis. A summary of electricity end-use in meat packing plants is provided in the following table.

Energy End-Use Activity for Electricity in Meat Packing Plants (in percent)

$\begin{array}{lr}\text { Refrigeration } & 37 \\ \text { Process Preparation, Cooking, Packing } & 18 \\ \text { Rendering } & 12 \\ \text { Lighting } & 14 \\ \text { Compressed Air } & 5 \\ \text { HVAC Equipment } & 4 \\ \text { Steam and Water Use } & 4 \\ \text { Waste Treatment } & 4 \\ \text { Other Total } & 2 \\ & 100\end{array}$

The last major category of energy use in meat packing plants is the direct use of fuels. These fuels are typically the same as those for boiler operations but are used as a direct heat source rather than to produce steam. This makes them inherently more energy efficient. The following table lists the end-uses of direct fuels in an average meat packing plant. 


\section{Energy End-Use of Fuels for Non-Boiler Operations in Meat Packing Plants}

(in percent)

\begin{tabular}{lr} 
Smoke House, Cook Ovens & 30 \\
After Burners & 20 \\
Gas/Hog Singers & 20 \\
Gas/0il Space Heating & 15 \\
Other Process, Hot-Water Heating, \\
\multicolumn{2}{l}{ Refrigeration, Gas (Dock Vehicles) } \\
$\quad \underline{10}$ Total
\end{tabular}

All of the above energy end-uses were affected by the housekeeping and smallcapital improvement projects undertaken by Oscar Mayer and Company.

Decar Mayer and Company, a subsidiary of General Foods Corporation, is one of the 1 argest producers and merchandisers of meat products in the United States. In 1979 , Oscar Mayer had $\$ 140$ million in sales and $\$ 42$ million in net income. The company's domestic meat operations accounted for $95 \%$ or more of these sales (Moody's, 1980). The Oscar Mayer Company markets processed meat products such as lunch meat, wieners, link sausage, bacon, ham products, and sandwich spreads. They also sell fresh meat, lard, by-products, pickled vegetables, and miscellaneous food products. The company operates three major slaughtering plants and eight principal meat processing plants. At two locations, both slaughtering and processing are performed.

This case describes energy conservation at two of 0scar Mayers plants located in Perry, Iowa, and Beardstown, Illinois. The Perry, Iowa plant slaughters hogs and produces 330.9 million pounds of pork per year; the Beardstown, Illinois plant slaughters hogs and produces 359.6 million pounds of pork per year. This case examines the housekeeping and low-budget capital improvements for energy conservation made at both plants since 1972. At the headquarters level, Oscar Mayer has instituted an energy department to aid in conservation improvements and to monitor changes in energy consumption at all plants. The Perry, Iowa and Beardstown, Illinois plants are the best examples of the success of this program. 


\section{CONSERVATION MEASURE}

Energy usage at the Perry, Iowa, and Beardstown, Illinois plants has dropped because of installatis: of low-cost capital projects and the implementation of housekeeping operations and maintenance procedures. Both of these methods were initiated after thorough plant-wide audits were made at both facilities. The opportunities identified in the audits were divided into high- and low-cost conservation measures. The low-cost measures, which are under discussion here, gain approval more easily and can be quickly implemented. Individually, they represent only a small savings in energy. Collectively, however, as will be shown, they can save a very large amount of energy. The following discussion will describe some of the methods for reducing consumption of boiler fuel, purchased electricity, and direct use fuel (Energy Task Force, n.d.).

The four major ways to reduce boiler energy use are to:

1. improve and maintain boiler efficiency

2. reduce heat losses from boilers

3. reduce heat losses in distribution systems

4. reduce steam consumption by recovering waste heat.

The use of advanced combustion control of the air-to-fuel ratio as well as closer monitoring of the boilers are techniques that increase boiler efficiency. Boiler maintenance should be periodic and should include a thorough check of scale build up in the boiler tubes and walls. All condensate should be returned to the boiler from rendering and other processes to heat incoming feed waters. The flash steam of high-pressure condensate should also be used as a heat source. An economizer should be installed to preheat air or water. Steam traps in the distribution lines should be checked periodically, and proper insulation should be used around all hot pipes. The use of the boiler should be optimized in terms of loading by distributing the use of boiler steam throughout the day. This is accomplished by off-peak production scheduling of process operations to avoid costly startup and shutdown of boilers.

Many of the above techniques can be used to reduce the direct use of fuels. The 0scar Mayer plants use natural gas, but the techniques can be applied to 
any other direct fuel type as we11. The three major ways to reduce direct fuel energy use are to:

1. improve and maintain burner efficiency

2. reduce heat losses in distribution systems

3. recover and use waste heat.

The space heating requirements of buildings can be reduced by using insulation and by complying with building standards. All burners should be maintained in top working condition, which entails frequent monitoring of the air/gas mixture levels and checking burners for build-up of scale. Any waste heat streams that are not being used for heating plant cleanup water, feed water to the boiler, or air to the burners are potential energy sources that should not be overlooked. All ventilation and heating ducts should be properly insulated to prevent heat losses. Energy management practices such as reducing the heat level when the building is not in use, installing air seals around truck loading dock doors, keeping doors closed when not in use, and maintaining a lower temperature during the winter season can be used to reduce energy consumption.

The last major types of energy conservation techniques to be considered are electricity saving methods. The three major ways to reduce electricity use are to:

1. reduce the demand or load on electrical equipment

2. increase the efficiency of electrical equipment

3. recover any waste heat from electrical equipment.

The use of more efficient replacement motors and pumping equipment will reduce demand considerably. The conversion of lighting sources to fluorescent, mercury, sodium, or high-intensity direct lighting will also reduce the amount of electricity consumed. Demand can be directly eliminated if natural lighting is used, when possible, or if intense lighting is used only in task areas. Exterior building and grounds illumination as well as general illumination should also be reduced to the safest allowable level. Air conditioning should be used only in work areas, and the thermostats should be set higher. Air conditioning should not be used if cooler outside air can be brought in. 
In addition, all compressed air lines should be checked periodically for leaks, and compressors should not be left on during nonworking hours. All motor driven equipment should be properly maintained and lubricated to reduce the electrical load. Refrigeration demand can be reduced by operating near the required temperature for frozen or cooled products, but not substantially below the required temperature. The use of insulation, weather stripping, and air curtains are other ways of reducing refrigeration demand. When possible, waste heat should be recovered from refrigeration and electrical equipment used to heat the plant's water or air.

A11 of the above measures can be used to reduce the energy used in meat packing plants as well as in many other process industry plants. The next section will illustrate the results of these low capital investment items or housekeeping innovations on energy use in the two Oscar Mayer plants.

PLANT PROCESS MODIFICATIONS

In 1972, the Perry and Beardstown plants used $1270 \mathrm{Btu} / \mathrm{lb}$ and $1100 \mathrm{Btu} / \mathrm{lb}$ of product, respectively. The energy department at headquarters performed energy audits of both facilities and, with the cooperation of the plant engirsering and production personnel, began to implement the techniques described above. Periodic audits were made, and reports were written to assess the impact and progress of both facilities in reducing energy consumption. Most of the measures instituted by the plants were intended to reduce natural-gas consumption rather than electricity consumption, because of the ease with which these techniques could be applied. Table 10.1 shows the decrease in usage from 1972 to the third quarter of 1981 on a Btu/lb-of-product basis for both plants. The decrease in energy usage was accomplished when both plants were undergoing expansion of their physical facilities. The decrease, therefore, reflects a conservative estimate of the energy saved.

\section{ENERGY SAVINGS}

Table 10.1 shows that energy usage dropped about $43 \%$ to 720 Btu/lb of product in 1981 at the Perry, Iowa plant. The Beardstown, Illinois plant reduced its energy consumption to $860 \mathrm{Btu} / 1 \mathrm{~b}$ of product in 1981, which is a decrease of about $22 \%$. This results in an energy savings of 182 billion Btu/year (1270 - 
$720 \mathrm{Btu} / \mathrm{lb}) \times 3.309 \times 10^{8} \mathrm{1b} / \mathrm{yi}$ at the Perry, Iowa plant and 86 billion Btu/year (1100-860 Btu/lb) $\times 3.596 \times 10^{8} 1 \mathrm{~b} / \mathrm{y}$ r at the Beardstown, Illinois plant.

To arrive at an energy cost savings for each plant, the amounts of natural gas (primarily burned as boiler fuel) and electricity that were used must be determined. Table 10.2 details the quantities of gas and electricity used at each plant, the price for each, and the total spent on energy in 1980. Table 10.2 also shows the energy saved at each plant in 1980 based on 1972 usage. The amount of gas usage dropped $34 \%$ at the Perry, Iowa plant and $25 \%$ at the Beardstown, Illinois plant. Electricity savings were $2.5 \%$ at both plants in 1980 compared to 1972 usage. In 1980, the total cost savings at the Perry and Beardstown plants, due to energy conservation measures, were about $\$ 250,000$ and $\$ 200,000$, respectively. These savings represent a reduction in the total energy bill of $17 \%$ at the Perry, Iowa plant and $12 \%$ at the Beardstown, Illinois plant.

To achieve these energy savings, approximately $\$ 75,000$ per year was spent on the conservation measures outlined in the previous sections. Data contained in Table 10.2 show that most of the improvements have been in the reduction of gas usage at both plants.

DECISION PROCESS

The payback period for each individual housekeeping project is hard to quantify but, assuming that about $\$ 100,000 /$ year was saved and $\$ 75,000 /$ year was spent over the five years of conservation effort, the total average payback period is less than one year. The easiest and least costly projects were undertaken first and they usually dealt with gas-saving techniques. The focus has now shifted more toward electricity saving projects because of the high cost per Btu of electricity and rising utility rates. These new programs will require cooperation between headquarters and the production plants. The involvement of production personnel in housekeeping energy conservation programs has led to many benefits other than cost savings. The attention to detail inherent in the housekeeping measures has improved operating efficiency and equipment maintenance. In the future, Oscar Mayer hopes to achieve savings at its other 
facilities through similar conservation efforts.

TABLE 10.1. Energy Usage (al1 figures Btu/1b of product)

$\begin{array}{crrrrr}\text { Plant } & 1972 & 1975 & 1979 & 1980 & 1981 \\ \text { Perry, Iowa } & 1270 & 1100 & 1010 & 900 & 720 \\ \text { Beardstown, Illinois } & 1100 & 1010 & 920 & 880 & 860\end{array}$

(:) Average for the year based on production and energy usage through the third quarter. 
TABLE 10.2. Housekeeping Cost Savings
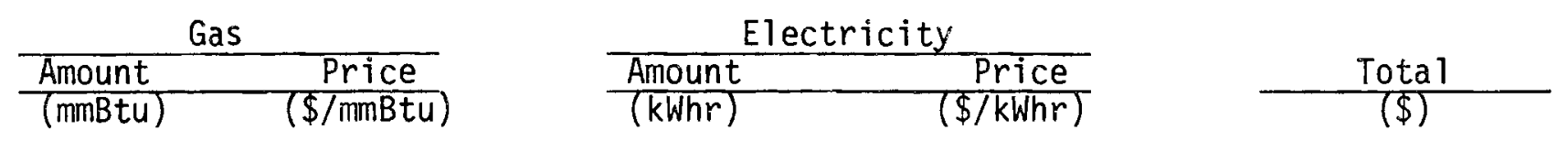

Perry, Iowa

\begin{tabular}{|c|c|c|c|c|c|}
\hline $\begin{array}{l}\text { Energy used }(1) \\
\text { per year }\end{array}$ & 240,000 & 2.85 & $18,700,000$ & 0.043 & $1,488,100$ \\
\hline $\begin{array}{l}\text { Energy saved } \\
\text { per year }\end{array}$ & $81,600(34 \%)^{(2)}$ & 2.85 & $467,500(2.5 \%)^{(2)}$ & 0.043 & $252,660(17 \%)$ \\
\hline \multicolumn{6}{|c|}{ eardstown, Illinois } \\
\hline $\begin{array}{l}\text { Energy used (1) } \\
\text { per year }\end{array}$ & 240,000 & 2.92 & $24,000,000$ & 0.041 & $1,684,800$ \\
\hline Energy saved & $60,000(25 \%)^{(2)}$ & 2.92 & $600,000(2.5 \%)^{(2)}$ & 0.41 & $199,800(12 \%)$ \\
\hline
\end{tabular}

(1) Based on 1980 figures

(2) As compared to 1972 figures 


\section{REFERENCES}

Casper, M. E. (ed.). 1977. Energy-Saving Techniques for the Food Industry. Noyes Data Corporation.

Energy Task Force. (no date) Meat Plant Energy Conservation Guidelines. Energy Task Force, American Meat Insititute, Washington, D.C.

Moody's Investor's Services, Inc. 1980. Moody's Industrial Manual. Vol. 2, New York, NY.

U.S. Department of Agriculture. 1980. Agricultural Statistics 1980. U.S. Government Printing Office, Washington, D.C.

U.S. Department of Conmerce. 1981. "Fuels and Electric Energy Consumed." 1979 Annual Survey of Manufacturers. M79(AS)-4.1, Bureau of Census, Washington, D.C. 


.

